\title{
Fosas comunes, paisajes del terror ${ }^{1}$
}

\section{Mass Graves, Landscapes of Terror}

\author{
Francisco Ferrándiz \\ Grupo de Investigación Antropología Comparada de España y América ACEA. \\ Centro de Ciencias Humanas y Sociales. CSIC. Madrid
}

Para Chun, por su coraje exquisito

\section{RESUMEN}

Las exhumaciones de fosas comunes de la Guerra Civil española y la posguerra de la última década, muy especialmente de fosas abandonadas de la retaguardia franquista, se han colocado en un lugar central de los debates contemporáneos sobre la naturaleza y alcance de la contienda y el régimen que surgió de ella. En este artículo, se analiza la complejidad y dinamismo del proceso, que incluye desde iniciativas políticas y judiciales de enorme proyección pública y mediática, como la Ley de la Memoria o el contro-

${ }^{1}$ Este texto se basa en una investigación de campo "multi-situada" (Marcus 1995) de más de cinco años sobre el ciclo más reciente de exhumaciones de fosas comunes de la Guerra Civil española, llevada a cabo en diversos escenarios entre lo que cabe destacar: actos conmemorativos, conferencias sobre la memoria, presentaciones de libros, exposiciones artísticas, exhumaciones (Valdediós, 2003; Villamayor, 2004; Fontanosas, 2006; Villanueva de la Vera, 2008, entre otras), reinhumaciones, diversas ONG de 'recuperación de la memoria histórica' (especialmente ARMH y 'Nuestra Memoria'), grupos de trabajo con apoyo institucional (Sociedad de Ciencias Aranzadi) y laboratorios forenses. La investigación también incluye la recopilación sistemática de artículos de prensa, noticias y documentales televisivos, y trabajo de campo en la Internet, donde circula mucha información (y también desinformación) sobre los distintos aspectos de la recuperación de la memoria histórica de la Guerra Civil y se producen intensos debates sobre las exhumaciones y sus circunstancias. Mi sincero agradecimiento a Lucio García Tornero, Luis Ragel, Marisa Hoyos y Jimi Jiménez por su amabilidad durante la exhumación de Villanueva de la Vera, y a Lucio García Tornero, además, por su paciencia ante mis repetidas llamadas durante el proceso de redacción de ese artículo. Quisiera agradecer también las sugerencias de Luis Díaz, María García, Julián López, Pedro Tomé y Javier Rodrigo. A María García, gracias por prestarme su copia del Semanario Gráfico Nacional Sindicalista del 25 de noviembre de 1939 (ver figura 6). Esta investigación se ha llevado a cabo gracias al Proyecto Intramural Especial (PIE) 2007101006 del CSIC. 
vertido auto de Garzón sobre los crímenes del franquismo, hasta acciones locales a veces fallidas, imperceptibles o efímeras, pero no menos cruciales. Desde el punto de vista de muchos de los actores sociales implicados en las exhumaciones, reabrir las fosas forma parte de un ejercicio básico de justicia y 'dignificación', al mostrar la magnitud y sistematicidad de la represión y revertir una situación insostenible de disposición 'infrahumana' de los cadáveres de las personas fusiladas, cristalizada en la expresión 'tirados' o 'enterrados como perros', usada con frecuencia para justificar las exhumaciones. Las políticas de dignificación o 'rehumanización' de estos muertos mal enterrados están incorporando en los últimos meses elementos provenientes del derecho transnacional, como el concepto de 'crímenes contra la humanidad'.

Palabras clave: Antropología de la Violencia y el Sufrimiento Social; Fosas Comunes; Desapariciones; Políticas de Dignificación; Políticas de la Memoria; Justicia Transnacional; Guerra Civil española.

\section{SUMMARY}

The recent exhumation of mass graves from the Spanish Civil War and the Post-War years, mostly involving the largely abandoned graves of the Francoist rearguard, have become a central element in contemporary debates about the conflict and the regime following it. In this paper, the complexity and dynamism of this process is analysed, including from political and legal initiatives of great social and media impact to local actions on the ground, at times failed, ephemeral or almost imperceptible, but no less crucial. From the point of view of many of the people involved in the pro-exhumation associations, opening up the graves is part of a basic exercise in justice and 'dignification', showing the scope and systematic nature of repression while reverting the 'infrahuman' disposition of the executed corpses, a feeling crystallised in the common expression 'thrown' or 'buried like dogs', used very often to justify the need of carrying out exhumations. Politics of dignification and 'rehumanization' of these 'incorrectly' buried bodies are incorporating, in the last few months, elements drawn from international law, such as the concept of 'crimes against humanity'.

Key Words: Anthropology of Violence and Social Suffering; Mass Graves; Disappearances; Human Dignity; Politics of Memory; Transnational Justice; Spanish Civil War.

\section{ESPASMOS JUDICIALES Y MEDIÁTICOS}

El 30 de octubre de 2008 empezaron los trabajos para la búsqueda de los cuerpos de cinco mujeres en el paraje conocido como "Las Albarizas" de la aldea de Tudal, situado en el municipio de Villanueva de la Vera, Cáceres. Florentina Quintana Huertas, sus dos hijas Ángela y Ana Tornero Quintana, Úrsula Sánchez Mate y Bernarda García Hernández habían sido asesinadas el 26 de septiembre de 1936 por un grupo de diez falangistas de su mismo pueblo. La excavación de los dos emplazamientos donde los testimonios orales situaban sus tumbas tuvo lugar en medio de una convul- 
sa tormenta judicial y mediática desatada por la decisión del Juez Baltasar Garzón de declarase competente para juzgar los crímenes del franquismo en un controvertido auto firmado el 16 de octubre, apenas dos semanas antes. Desde la Audiencia Nacional, el Juez Santiago Pedraz había autorizado esta excavación un día antes de que comenzara a removerse la tierra en Las albarizas, junto con, entre otras, la de la 'caja colectiva o columbario' 198 del Valle de los Caídos, donde se encuentran los cuerpos de 7 personas del pueblo abulense de Pajares de Adaja fusiladas el 20 de agosto de 1936 por tropas franquistas en Aldeaseca, posteriormente exhumados y trasladados en 1959 al Valle en el marco de un rocambolesco operativo a escala nacional de captación de cadáveres para el ahora cuestionado mausoleo de Franco $^{2}$. En esa misma Providencia, se autorizaban las condiciones de 'privacidad y dignidad de las víctimas y sus familiares' para la exhumación de la fosa donde podrían encontrarse los restos de Francisco Galadí, Dióscoro Galindo, Joaquín Arcollas y Federico García Lorca, solicitadas por la familia de este último.

Este espasmódico itinerario judicial había empezado el 14 de diciembre de 2006, cuando diversas asociaciones interpusieron demandas en el Juzgado Central de Instrucción número cinco de la Audiencia Nacional, cuyo titular es Baltasar Garzón, solicitándole que se declarara competente para investigar y juzgar presuntos delitos de detención ilegal "fundamentalmente por la existencia de un plan sistemático y preconcebido de eliminación de oponentes políticos a través de múltiples muertes, torturas, exilio y desapariciones forzadas ${ }^{3}$ (detenciones ilegales) de personas a partir de 1936, du-

${ }^{2}$ También se autorizaba la exhumación de la caja individual 10.672 , situada en el Piso 1, Cripta África de la Basílica de la Santa Cruz del Valle de los Caídos, que contiene los restos de Fidel Canales, trasladado el 30 de diciembre de 1968 desde el cementerio de Griñón, donde se encontraba desde su muerte en el frente, al Valle. En la búsqueda tenaz del cuerpo de su padre y seis vecinos de Pajares de Adaja, así como el de su tío Fidel, Fausto Canales está contribuyendo a desenmascarar los aspectos más siniestros de esta monumental fosa común. Mi agradecimiento a Fausto por su amabilidad de siempre. Véanse también Sueiro 2006 [1976], Aguilar 1996: 116-129, y Solé 2008, así como el documental Franco: Operación Caídos, producido por Mediapro, presentado por Francisco González ('Gonzo'), y emitido por Antena 3 el 28 de enero de 2009.

${ }^{3}$ La creciente aplicación del apelativo desaparecidos en el caso español para referirse a las personas fusiladas durante la Guerra Civil y la posguerra (de momento fundamentalmente en el bando de los vencidos), impulsada con fuerza por el impacto público de las diligencias de Baltasar Garzón, ha generado una incipiente (y en ocasiones agria) controversia con ramificaciones judiciales, sociales, políticas, mediáticas e historiográficas, que será analizada en un futuro artículo. En el marco comparativo, para un reciente análisis crítico de la figura del 'detenido-desaparecido' como 'catástrofe de la identidad' en Argentina y Uruguay, véase Gatti 2008. 
rante los años de Guerra Civil y los siguientes de la posguerra, producidos en diferentes puntos geográficos del territorio español" ${ }^{\prime 4}$. Posteriormente, se personaron en el proceso otras iniciativas privadas y de otras asociaciones. La elección de juzgado de Garzón para presentar estas denuncias no era casual, sino parte de una estrategia que pretendía capitalizar su prestigio internacional, cimentado en su intervención en el 'caso Pinochet', y su visibilidad mediática con la esperanza de que, como mínimo, no fueran archivadas sin mayores consecuencias. Este desplazamiento de algunas asociaciones hacia la judicialización del proceso de recuperación de la memoria histórica tenían, por otra parte, su origen en una extendida insatisfacción en estos colectivos ante lo que consideraban tímidas propuestas y lentos avances de lo que el 27 de diciembre de 2007 se convertiría en la 'Ley 52/ 2007 por la que se reconocen y amplían derechos y se establecen medidas a favor de quienes padecieron persecución o violencia durante la guerra civil y el franquismo', conocida como Ley de Memoria Histórica 5 .

Para capturar la sensación de vértigo ya referida, haré un breve recorrido por algunos de los hitos más importantes de los últimos meses. El 29 de enero de 2008, el Ministerio Fiscal emitió un dictamen en el que se oponía a la admisión a trámite de las denuncias presentadas hasta el momento, recomendando su archivo. El 23 de junio Garzón pide al Ministerio del Interior y Defensa que le envíen los informes que tengan sobre desaparecidos, con la intención de probar que nunca había habido una investigación política o judicial previa sobre los hechos. A los denunciantes, les pide un listado completo de los datos que obran en sus manos. Es en este momento en el que empieza a extenderse entre los colectivos de recuperación de la memoria la sensación de que Garzón va a involucrarse, aunque desconocen las dimensiones y el recorrido jurídico que comienza a dibujarse en el horizonte. El 1 de septiembre, Garzón solicita al Abad del Valle de los Caídos, al archivo General de la Nación, a la Conferencia Episcopal, al Centro de Documentación de la Memoria Histórica y algunas alcaldías que aporten todos los datos que obren en su poder sobre los desaparecidos. Un día después, emplaza a las asociaciones denunciantes a entregar en 15 días la relación de desaparecidos y la ubicación de las fosas comunes donde pueden estar enterrados. El 22 de septiembre, representantes de la recientemente constituida Plataforma de Víctimas de Desapariciones Forzadas del Franquismo (PVDFF) entregan a Garzón un listado con 143.353 nombres y convocan una conferencia de prensa en el Ateneo de Madrid para explicar su posición.

\footnotetext{
${ }^{4}$ Véase el auto de Garzón de 16 de octubre de 2008, p. 3.

5 Véase http://www.boe.es/boe/dias/2007/12/27/pdfs/A53410-53416.pdf.
} 


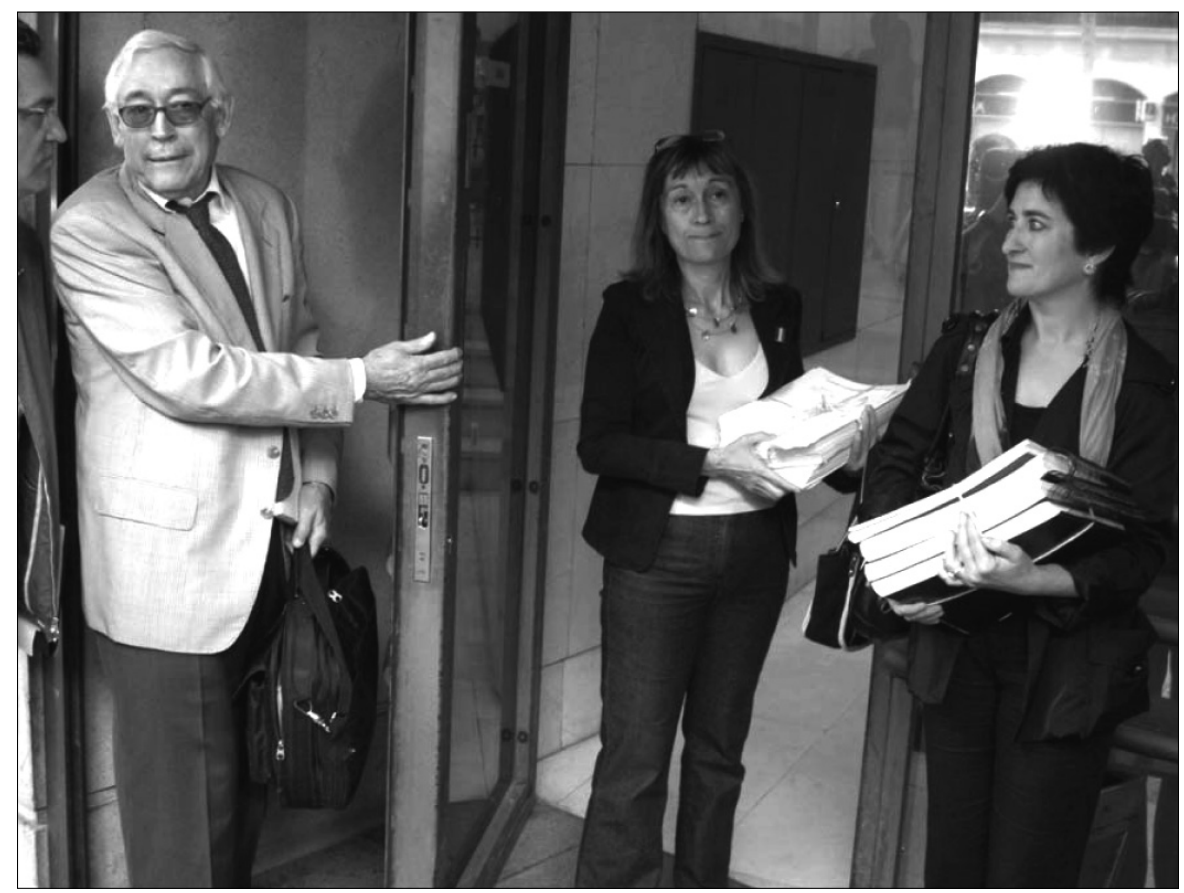

Figura 1: Miembros de la Plataforma de Víctimas de Desapariciones Forzadas del Franquismo a las puertas de la Audiencia Nacional el 22 de septiembre de 2008, con los listados conteniendo los nombres de más de 140.000 personas presuntamente desaparecidas durante la Guerra Civil y el Franquismo. De izquierda a derecha, Fausto Canales (ARMH Valladolid), Llani Álvarez (AMHyJA), y Francisca Maqueda (Vicepresidenta de la AMHyJA, y entonces Secretaria de la PVDFF). Fotografía del autor.

Cuando el 16 de octubre de 2008 el juez Baltasar Garzón acepta en un auto la competencia para tramitar la causa por presuntos delitos permanentes de detención ilegal en el marco de los crímenes contra la humanidad, contabilizando un total de 114.266 casos entre el 17 de julio de 1936 y diciembre de 1951, se produce un torbellino de enorme intensidad y corta duración en el que, en apenas cuatros semanas, se entremezclarían tecnicismos jurídicos con controversias políticas y una significativa tormenta mediática —no sólo dentro de España, sino también en el contexto internacional. En ese auto, recibido por el diario El Mundo en su editorial del día siguiente como 'truculenta garzonada", el juez consideraba que durante la Guerra Civil y el franquismo se habían producido graves violaciones de derechos asimilables a la categoría jurídica de crímenes de lesa humanidad y mantenía que el procedimiento de desapariciones forzadas fue usado 
sistemáticamente para entorpecer la identificación de las víctimas e impedir la actuación de la justicia hasta el día de hoy. Al tiempo, autorizaba diecinueve exhumaciones que habían sido solicitadas por las asociaciones y particulares demandantes, entre las que destacó durante unos días, en el marasmo mediático, la que sacaría a la luz los restos de Dióscoro Galindo González, Francisco Galadí Melgar, Joaquín Arcollas Cabezas y Federico García Lorca, enterrados en una fosa común envuelta desde hace años en una importante controversia. Un día después, en un nuevo auto, Garzón transforma las diligencias previas en sumario ordinario para dificultar el anticipado recurso de la fiscalía. Recurso de apelación ante la Sala de lo Penal que llega el 20 de octubre, firmado por el fiscal jefe Javier Zaragoza, que denunciaba el "singular andamiaje jurídico" plasmado por Garzón en su auto para justificar la aplicación del derecho penal (p. 3). Zaragoza argumentaba que se trataba de delitos "prescritos" (pp. 22-31) y "amnistiados" (pp. 31-35), y no de crímenes contra la humanidad'. Según el fiscal, descartada la "justicia de sanciones, que es quintaesencia del proceso penal", los hechos entrarían en el ámbito de las reparaciones morales a las víctimas — desglosados en términos de verdad, reconocimiento y reparacióninterpretables bajo el paraguas de la "justicia transicional o reparadora" y bien cubiertos por la Ley de Memoria Histórica (pp. 5-8).

El 29 de octubre, como vimos, el juez Pedraz, en sustitución de Garzón, dicta una providencia autorizando varias exhumaciones entre las que se encontraba, en primer lugar, la de Villanueva de la Vera. El 7 de noviembre la Sala de lo Penal, en reunión extraordinaria, acuerda paralizar las exhumaciones autorizadas en el marco de la causa abierta por Garzón hasta que se aclare su competencia en el caso. El 18 de noviembre, el propio Garzón emite un nuevo auto declarando extinguida su competencia, inhibiéndose y derivando la causa hacia los correspondientes Juzgados de Instrucción Territorial, enfatizando que su inhibición no significaba que los delitos no 'permanezcan' y que lo sigan siendo contra la humanidad. Además dejaba un sorprendente titular relacionado con los llamados "niños perdidos del franquismo", referido a un presunto "andamiaje pseudo jurídico que, presuntamente, dio cobertura a la sustracción sistemática de niños" hijos de madres y familias republicanas para ser educados en la afección al régimen entre 1937 y 1950 (incluyendo cambios de identidad), muchos de los cua-

\footnotetext{
${ }^{6}$ Dice Zaragoza en su recurso: "la calificación jurídica de los hechos denunciados como crímenes de lesa humanidad no es aplicable al caso, ya que el cuerpo normativo escrito y consuetudinario que conforma la legalidad penal internacional no existía al tiempo de la comisión de los hechos, y además semejante calificación jurídica no puede aplicarse retroactivamente" (p. 21).
} 
les estarían todavía vivos ${ }^{7}$. El 26 de de noviembre, el Tribunal Supremo publica una providencia en respuesta a petición de la nieta de Juan Negrín, donde declara que no existe ni razón ni fundamento legal para que dicha instancia judicial conozca esta causa. La decisión del Pleno de la Sala de lo Penal de la Audiencia Nacional, especificada en auto del 2 de diciembre de declarar, la "falta de competencia objetiva" del Juzgado Central número cinco en esta causa, dejando también sin efecto todos los actos y resoluciones posteriores, incluyendo el auto de inhibición, han desembocado en el estancamiento momentáneo de un proceso cuyas consecuencias —en el terreno de lo político, lo jurídico y lo simbólico— son aún difíciles de medir. En el momento de cerrar estas páginas, el 26 de diciembre de 2008, siguiendo la línea trazada en su auto de inhibición, Garzón envió a jueces de instrucción decanos de Burgos Barcelona, Madrid, Málaga, Valencia, Vizcaya y Zaragoza una resolución con información sobre "niños perdidos", instándoles a valorar su competencia en la investigación de estos casos.

Las asociaciones que se personaron en la causa han sufrido un desgaste importante en el proceso, en el que han sido tremendamente exigidas sin tener apenas respaldo institucional y sin contar con los medios necesarios para llevar a cabo con todas las garantías una investigación de esa magnitud. Las quejas ante la insuficiencia del voluntarismo y por la falta de apoyo fueron constantes. Además, la disolución el 29 noviembre de 2008 de la Plataforma de Víctimas de Desapariciones Forzadas del Franquismo (PVDFF), donde estaban representadas las asociaciones personadas en la causa de la Audiencia Nacional, y la creación en esa misma fecha de la nueva Coordinadora de Colectivos de Víctimas del Franquismo (CCVF) responde a una controversia entre los colectivos demandantes relacionada con la gestión del capital simbólico adquirido por el movimiento asociativo con la declaración de competencia de Garzón. Entre otros aspectos, se produjeron discrepancias respecto a la representatividad de algunos portavoces ante los medios de comunicación, así como con la composición de la Comisión de Expertos encargada por Garzón, de apenas unos días de vida. La nueva Plataforma justifica la refundación en una discrepancia mayor: lo que considera satisfacción de algunas asociaciones frente al desasosiego de otras (reunificadas en la CCVF) respecto a la actuación global de Garzón, incluyendo su decisión de inhibirse en la causa ${ }^{8}$. Esta nueva situación augura estrategias discrepantes y diversificadas de las diferentes asociaciones de cara al futuro

7 Auto del 18-11-08, pp. 49-75. Garzón basa su argumentación en la investigación de Vinyes (2002) y Vinyes, Armengou y Belis (2002) sobre las mujeres presas y los niños perdidos.

${ }^{8}$ Véase http://memoriadesaparecidos.blogspot.com/2008/12/comunicado-de-disolucinde-la.html. 
en el frente judicial, que todas consideran todavía abierto -incluso imparable- a pesar del contratiempo que supuso la inhibición del juez y la posterior declaración de incompetencia del Juzgado número cinco de la Audiencia Nacional para juzgar los crímenes del franquismo. Entre ellas, la remisión de los casos a los tribunales territoriales, siguiendo la línea trazada en el auto de inhibición de Garzón, el recurso al Tribunal Europeo de Derechos Humanos de Estrasburgo o el establecimiento de una línea de trabajo con el Grupo de Trabajo sobre Desapariciones Forzadas o Involuntarias de la Comisión de Derechos Humanos de la ONU ${ }^{9}$. Mientras agotan las instancias judiciales nacionales, los colectivos cívicos de recuperación de la memoria histórica, que han ido paulatinamente enriqueciendo sus demandas de retribución social, política, económica y jurídica de las víctimas de la represión de retaguardia franquista, parecen decantarse hacia el amparo de esquemas transnacionales de justicia. A la espera de noticias en el resto de los frentes abiertos, sobre el terreno, el trabajo continúa sin pausa.

\section{FOSAS DESAPARECIDAS}

Volvamos ahora a Villanueva de la Vera, para ilustrar cómo se experimenta y se gestiona en los ámbitos locales la topografía de la represión franquista, cuya eficacia sigue parcialmente vigente en la actualidad. Como vimos, era la primera exhumación emprendida en España tras la Providencia de Pedraz autorizando nuevas exhumaciones, cuando aún estaba sin resolver la competencia del juez Garzón para investigar los crímenes del franquismo. Ya hemos visto también que eran días de gran convulsión judicial, con novedades casi diarias, declaraciones políticas grandilocuentes $-\mathrm{O}$, en el caso del gobierno, silencio casi sepulcral - e importantes convulsiones mediáticas. Así, Villanueva se iniciaba en un ambiente ya cargado, pero era además una iniciativa muy emotiva en la lógica de las asociaciones que promueven exhumaciones en España, por su especial sinsentido, su crueldad y su cariz a todas luces 'inhumano'. Se buscaban, en dos fosas separadas por apenas dos centenares de metros, a cinco mujeres ajusticiadas por diez falangistas locales el 26 de septiembre de 1936. Se habían llevado a cabo en la zona prospecciones con georadar (GPR de $400 \mathrm{Mhz}$ ) cuyo resultado, plasmado en un informe técnico, detectaba y posicionaba en ambas zonas "anomalías electromagnéticas claras asociables a enterramientos clandestinos a una profundidad estimada de vaso de fosa de $1,50 \mathrm{~m}{ }^{10}$.

\footnotetext{
${ }^{9}$ Camino ya emprendido en 2002 por la ARMH. Véase Silva 2005: 80-82.

${ }^{10} \mathrm{La}$ prospección fue encargada por la Coordinadora de la Memoria Histórica de Extremadura, y el informe se elabora en abril de 2008. Las prospecciones con georadar
} 
La excavación, impulsada desde Villanueva de la Vera por Lucio García Tornero, miembro de la asociación Nuestra Memoria, estaba vinculada a la de otras dos fosas que se exhumarían unas semanas después en Valverde de la Vera, donde había ocho hombres entre los que se encontraban los maridos de dos de las mujeres enterradas en Villanueva. Lucio tenía razones de sobra para involucrarse en las siempre complejas y muchas veces frustrantes tareas necesarias para poner en marcha una exhumación, que incluyen no sólo conseguir los consensos y los permisos, negociar con las autoridades, atraer a alguno de los equipos técnicos disponibles o atender a la prensa, sino también, de manera muy especial, la gestión de las reverberaciones que se producen paulatinamente en el municipio, especialmente cuando se trata del ámbito rural. En Las Albarizas, en una de las dos fosas de las mujeres estaban enterradas su abuela y las dos hermanas de su madre, una de ellas embarazada al morir y con un bebé de quince meses. En Valverde, entre las dos fosas de los hombres, estarían un hermano, un primo hermano y un cuñado de su madre. De los trece fusilados buscados en ambas localizaciones, ocho hombres y cinco mujeres, seis eran familiares suyos. En sus propias palabras, con su esfuerzo no hacia sino "cumplir el sueño de la vida de mi madre", que siempre sintió mucho que una parte de la familia estuviera "tirada como perros en el campo".

El caso de Lucio —en cumplimiento del sueño de su madre- es paradigmático de la experiencia de muchos familiares que han atesorado, con discreción, a veces sigilo y en no pocas ocasiones temor, expectativas de rescate de sus familiares desde hace muchos años y que ahora, en el contexto de los acontecimientos de la última década, han podido paulatinamente salir del armario ${ }^{11}$. Lucio había estado interesado en desentrañar este crimen "toda la vida", y poco a poco fue recopilando detalles de los sucesos de aquéllos días, especialmente gracias a la "hermandad" semiclandestina que había en su pueblo entre las familias de las víctimas. En todo caso, "antes hablaba muy poco la gente". Lucio no tenía ninguna información sobre las

para la localización de fosas comunes se llevan haciendo esporádicamente desde el 2002, pero se han incorporado de manera más sistemática al proceso de exhumaciones, a través de Cóndor Georadar S.L., desde finales de 2006, cuando se utilizó para acotar la zona de exhumación de una fosa que contenía catorce cuerpos en Fuenteguinaldo (Salamanca), y en la búsqueda de fosas junto a las tapias del cementerio de Mérida. Gracias a Emilio Silva y Bonifacio Sánchez Cepa por aclararme este último punto.

${ }^{11}$ No se trata de una expresión retórica. Se la he escuchado en varias ocasiones a familiares de víctimas de la represión refiriéndose, como en el caso de la homosexualidad, a la superación pública y notoria de una situación previa de semiclandestinidad e incluso vergüenza, en este caso por pertenecer a familias de tradición roja castigadas por la represión. 
exhumaciones familiares de finales de los años setenta, paralizadas por el golpe de Tejero del 23 de febrero de 1981. "Cuando sucedió lo de Tejero, lo vi oscuro. La gente dejó de querer hablar, no había forma, había incluso más miedo que cuando vivía el propio Franco". En torno a 1988, a medida que se disolvía el temor a una involución política, volvió al tema con un interés renovado, gracias a su trabajo con el historiador Julián Chaves, que estaba investigando entonces la represión en la provincia de Cáceres para su tesis doctoral. Pero no empezó a ver claro que se podía intentar rescatar los restos hasta que se convenció de que iba adelante la Ley de la Memoria que, al menos, prometía cobertura legal a iniciativas como la suya. Entonces, a través de su amigo Luis Ragel, se puso en contacto con Emilio Silva (Presidente de la ARMH), y a partir de ese momento se empezó a planificar la exhumación. Las personas que se buscaban entre Villanueva y Valverde aquellos días eran, según Lucio, "todos desaparecidos", víctimas del terror caliente de los primeros meses de la contienda, sin juicio ni garantías de ningún tipo, como no pocos de los fusilados en la retaguardia franquista que sobrevuelan las páginas del auto de Garzón. A pesar de su investigación de años, Lucio no haba conseguido encontrar documentación alguna de ninguno de los casos, y todo lo que se conocía sobre lo que presuntamente sucedió en Villanueva se remitía a narrativas orales compartidas en contextos familiares, entre familias de víctimas y, más recientemente, en la calle y otros ámbitos públicos del pueblo, a medida que se acercaba la exhumación y se movilizaban las diversas expectativas respecto a ella, desde la indiferencia y el rechazo hasta la implicación incondicional.

Así rezaba, tras la enumeración de las cinco mujeres, sus edades, condición, oficio y descendencia, así como su distribución en las dos fosas, una fotocopia distribuida entre los asistentes a la exhumación de Villanueva, redactada por el propio Lucio.

Las circunstancias de sus muertes han sido reconstruidas a partir de testimonios de familiares y vecinos y constituyen parte de la memoria histórica que se conserva en el municipio sobre los sucesos que se produjeron entre los meses de julio y septiembre de 1936. En los primeros días de septiembre varias mujeres indefensas fueron sacadas de sus casas en Villanueva por falangistas reconocidos del municipio. Estuvieron retenidas en el Ayuntamiento, utilizado en aquellos días como cárcel. Fueron rapadas, obligadas a barrer de forma vejatoria las calles del municipio y, finalmente, conducidas a 'Las Albarizas' y obligadas a recolectar carillas, donde fueron tiroteadas por los pistoleros que las custodiaban.

"Fueron cazadas como palomas", se comentaba en el entorno de la exhumación, muy condicionado en esta ocasión por la presencia descompensada de medios de comunicación. Según Lucio, en una de las piruetas del reciclaje generacional de memorias familiares, esa era la expresión que una 
sobrina de Bernarda (una de las mujeres asesinadas) ponía en boca de su abuela, la madre de la propia Bernarda. Las circunstancias específicas de violencia de género que subyacían a esta excavación, su coincidencia con el momento más álgido del efecto-Garzón y su vinculación judicial directa con la Audiencia Nacional la convirtieron en una fosa mediática sobre la que se había levantado mucha expectación ${ }^{12}$. En un momento de 'limbo judicial', sin saber exactamente cómo ni dónde encontrarlo, se buscaba con afán pero sin resultados visibles el rastro del famoso juez en los protocolos de exhumación, en las decisiones de los técnicos responsables, o en la actitud y las declaraciones de los familiares. Desde que se iniciaron por la mañana los trabajos de localización de la primera de las fosas con una excavadora, coordinados por Marisa Hoyos (ARMH) y el arqueólogo Jimi Jiménez (Sociedad de Ciencias Aranzadi), estaban presentes varios equipos de filmación profesional, entre los que se encontraban varias televisiones (dos de ellas extranjeras) y dos equipos de documentalistas. También estaba allí el programa 'Esquina Viva' de Canal Extremadura Radio, y se presentaron en diferentes momentos reporteros de varios periódicos y agencias informativas regionales y nacionales ${ }^{13}$. A medida que trabajaba la pala, cada momento de sospecha sobre la presencia de la fosa era observado con la máxima atención y registrado con el expectación de un hallazgo material concreto -idealmente un indicio de una fosa bien preservada-, que vinculara definitivamente el caso español con los flujos de justicia transnacional con los que empezaba a converger. Pero 'noticias' de impacto hubo pocas, lo que no debe interpretarse como que el proceso de exhumación y los ciclos narrativos que le acompañaron no fueran cruciales en la negociación de las memorias de la represión franquista en Villanueva, en la propia comarca de la Vera o, como ocurre con todas y cada una de las exhumaciones, en el ámbito nacional.

Los trabajos de prospección acabaron a las cinco de la tarde, sin haber encontrado nada más que una capa de menos de medio metro de tierra apelmazada sobre un lecho freático, situación descorazonadora para muchos de los presentes. Una persona que había conocido en la exhumación, Marcos Rodríguez Peña, miembro del Foro por la Memoria, me llevó a visitar

\footnotetext{
12 Sobre el impacto de los medios de comunicación acerca de las exhumaciones y los debates entre las asociaciones sobre este impacto, véase Ferrándiz 2005. Sobre el proceso de ‘digitalización' de la memoria, véase Ferrándiz y Baer 2008.

${ }^{13}$ Entre las televisiones, estaba la cadena ARTE franco-alemana, una televisión canadiense, Canal Extremadura TV y la TVE regional. Por la tarde apareció TVE nacional. Entre los periódicos que cubrieron la noticia, estaban, sobre el terreno, el Periódico de Extremadura y Hoy, Público y la Agencia EFE. Durante los días siguientes a la exhumación, salieron también notas informativas en El Mundo (una página), el ABC, La Razón, El País, 20 minutos y otros.
} 


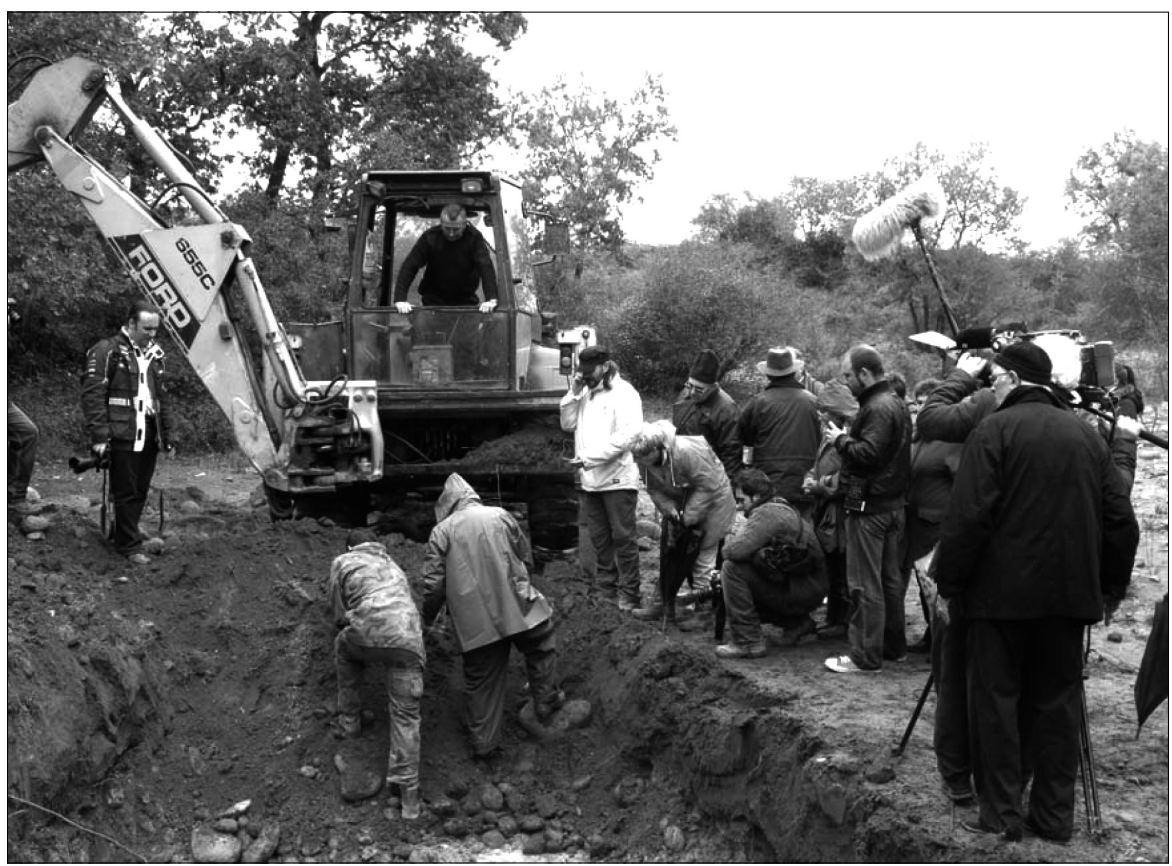

Figura 2: 30 de octubre de 2008. Prospección en torno a la fosa que contendría los restos de Úrsula Sánchez y Bernarda García en el paraje de Las Albarizas del Tudal (Villanueva de la Vera, Cáceres). Fotografía del autor.

la ubicación de otra fosa en el término municipal de Madrigal de la Vera, último pueblo de la provincia de Cáceres en la ruta hacia la provincia de Ávila. Los itinerarios de activistas de la memoria como Lucio o Marcos se tejen en cruces constantes con este tipo de localizaciones vinculadas a fusilamientos, con familiares que acuden a ellos, con las narrativas orales más o menos incipientes o estructuradas sobre los sucesos, y con fragmentos de documentación de diversa procedencia, desde papeles encontrados en los archivos a cartas o fotografías privadas que salen a la luz en el contexto de una investigación. En su extremo más organizado e institucionalizado, nos encontramos con casos como los mapas de fosas y los proyectos de recuperación de todos los nombres de los fusilados, algunos de los cuales han tenido apoyo institucional y están en la base de la documentación presentada al juez Garzón ${ }^{14}$. En el menos vertebrado, con casos como el de Ma-

${ }^{14}$ Véanse por ejemplo, el proyecto 'Todos los nombres de Andalucía' (http:// www.todoslosnombres.org/), o el de 'Todos los nombres de Asturias', que tiene 17.700 nombres en la base de datos, incluyendo fusilamientos y muertos en combate (http:// www.todoslosnombres.es/). Páginas visitadas el 4 de enero de 2009. 
drigal donde, además, la situación que se daba era muy distinta de la de su vecina Villanueva.

En este caso se trataba de una posible fosa no investigada aún ni por activistas locales ni por profesionales, sin conocimiento público de las personas que pudieran estar dentro, y sin ningún familiar que estuviera próximo a solicitar una intervención en ella. Sin embargo, como en no pocos otros lugares de la topografía de la represión franquista, la presunta fosa no había llegado a perder su visibilidad en el paisaje, a caballo entre la continuidad, cada vez más atenuada, de su eficacia aterrorizadora y una geografía de resistencia (Pile 1997) semiclandestina, expresada en el respeto a la relativa paz de los muertos, aunque sean anónimos y estén mal enterrados. O precisamente por ello. En la parte baja de un campo de cultivo que trepaba por una ladera, había un espacio ovalado cubierto por hierba, sin arar. Así llevaba desde hace décadas. "Algún familiar tendría que darle las gracias al hombre de la finca, porque el hombre, siempre lo ha respetado, toda la vida...", me decía Marcos. Y me contó allí la siguiente historia: una noche, los perros de un pastor que se encontraba en la zona, se pusieron a ladrar, nerviosos. El pastor que estaba allí pudo oír en la lejanía algunos gritos pidiendo clemencia. “No me matéis, que tengo cuatro hijos'... o no sé cuántos serían", recreaba Marcos en su improbable ventriloquia. La súplica y los aullidos de aquellos perros en la noche han quedado en la memoria de la zona como el marcador más claro de que hubo un fusilamiento. Marcos no sabía quién podía estar dentro de esa fosa, y sólo una persona en el pueblo había apuntado la posibilidad de que, según lo que le había contado su padre en varias ocasiones antes de morir, su abuelo fuera uno de ellos. Es el único. "Lo demás, hablas con la gente por la calle y nada... aquí lo que falta es uno que diga: 'ahí está mi abuelo'”.

De regreso al paraje de Las Albarizas del Tudal, ya prácticamente sumido en la noche, había novedades en la casa de campo de los familiares de Úrsula, en el que estaban refugiadas de la lluvia intermitente las pocas personas que aún permanecían en el entorno de la exhumación. El tono desolado de las conversaciones que había dejado un par de horas antes se había tornado en renovado entusiasmo. Claro, comentaban, habían pasado rozando la tumba con la máquina. Un anciano pastor se había acercado a la zona y, reconstruyendo los testimonios que él mismo había escuchado a lo largo de su vida, había propuesto una nueva localización de la fosa justo unos metros más allá del área prospectada. Las personas que estaban en la casa habían bajado de nuevo al campo donde supuestamente se encontraba la fosa para discutir sobre el terreno con los arqueólogos las características del nuevo emplazamiento, la medida en la que concordaban o no con los testimonios que habían sido recogidos en los meses anteriores, y las posi- 


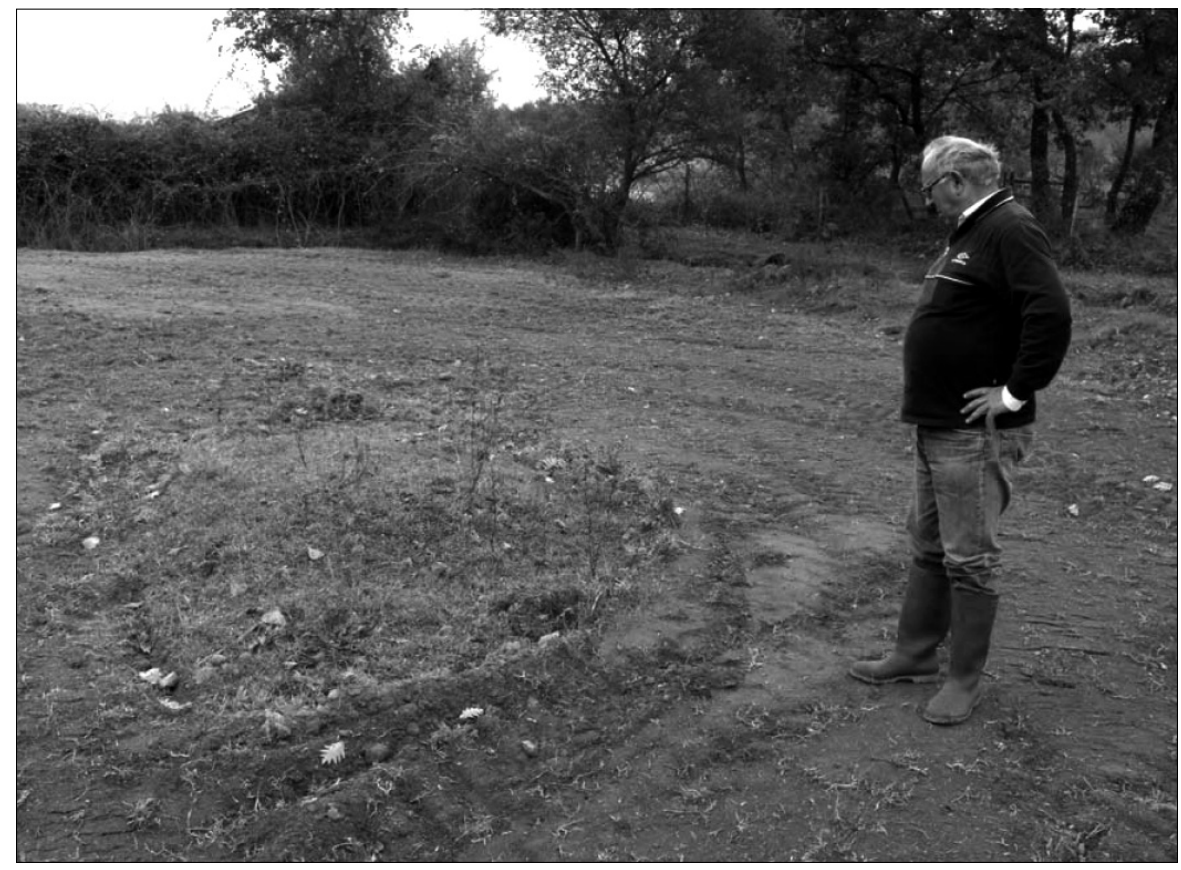

Figura 3: 30 de octubre de 2008. Marcos López Peña contempla el lugar no arado durante setenta años en las afueras de Madrigal, Cáceres, donde según algunos lugareños se encontraría una fosa común. Fotografía del autor.

bilidades de que, si acaso estuvieran allí enterradas Úrsula y Bernarda, se conservaran sus restos. Lucio utilizó su péndulo para, caminando varias veces sobre el lugar, tratar de arrancarle algún mensaje de esperanza al poco prometedor paraje, tan cercano al poco profundo nivel freático como el resto del prado.

Mientras me contaban los nuevos eventos, llegó a la casa la dueña del terreno, Consuelo, que eligió ese momento para compartir con los familiares de las mujeres asesinadas que la persona que le vendió la tierra hacía 28 años le había recomendado que no removiera la tierra bajo cuatro incipientes brotes de roble, si no quería encontrarse con restos humanos de la guerra. De nuevo, el arado había dudado y se había detenido en el entorno de una presunta fosa. Este emplazamiento estaba justo al otro lado de la zona removida en relación al lugar señalado por el pastor, pero duplicaba el número de opciones a explorar al día siguiente. Bajamos de nuevo al lugar donde la pala excavadora había estado abriendo el terreno durante todo el día. Allí, ya en la práctica oscuridad, Charo, recreó de nuevo la 
conversación que tuvo con el antiguo dueño de la finca y demostró conocer bien la versión de los sucesos del 26 de septiembre de 1936 que circulaba con más fuerza en el entorno de la excavación. Las narrativas que sobrevuelan la búsqueda y, en su caso, apertura de las fosas, más o menos fugitivas, fragmentadas o consolidadas, son un elemento central de la exhumación y, como veremos después, del itinerario de dignificación del recuerdo de los fusilados (Ferrándiz 2008). "Lo mismo esta veguilla la quieres arar, o sembrarla de algo', me dijo, 'y el tema es ese...". "Me advirtió de que tuviera mucho cuidado, que si pasaba el tractor, que no me fuera a sorprender porque había unas mujeres enterradas". "Luego ya me contaron la historia, mi padre y demás... que cómo las habían fusilado y demás... Y digo, 'ay, que sitio que he ido a comprar, Dios mío...' Y luego ya dije, 'mira, si están ahí las pobrecitas, que descansen'. Las pusieron a coger carillas ¿no?, y una de ellas estaba embarazada". "Esa está en la otra fosa", le precisaron. "Y a un señor que le dijeron que la rematara", continuó Charo, "no sé, se puso enfermito y, no sé... me dijeron el nombre... se murió a los dos meses... Porque por lo visto se movía y era el niño". "Mi abuela creo que tenía un puñado de carillas en la mano... Las dispararon por la espalda... estuvieron jugando con ellas todo el día”, concluyó una de las nietas de Úrsula Sánchez.

Unas semanas después me completaría Lucio la parte final de la historia, que se había matizado y enriquecido con el testimonio de los descendientes de algunas personas vinculadas con el suceso y que hasta entonces se habían mantenido al margen. Los falangistas habían pedido a un grupo de labradores y albañiles que estaban en la zona que enterraran los cuerpos. El maestro de obra de un secadero que se estaba construyendo allí les dijo que una de ellas se movía. "Dale con el cotillo de la azada en la cabeza", le ordenaron, a lo que se negó. Dos de los falangistas, entonces, la rematarían ellos mismos. El albañil, según lo que le contó su hijo a Lucio días después de la exhumación, "nunca volvió a ser igual, dormía con un machete bajo la almohada, temblaba, enfermó y murió muy pronto". La exhumación había revelado la existencia de un muerto de pena relacionado con el fusilamiento, y sus familiares también habían encontrado en ella el espacio para contar su historia.

Seguía chispeando sobre el prado de Las albarizas. Como había ocurrido durante toda la jornada, algunos de los técnicos y activistas seguían recibiendo llamadas en el teléfono móvil pidiendo ayuda para localizar o exhumar restos en la región, o información para completar una crónica. Lucio caminaba pensativo sobre el lugar, ida y vuelta, ida y vuelta. Su péndulo se calentó, marcando alguna presencia bajo el terreno, pero emitía un men- 


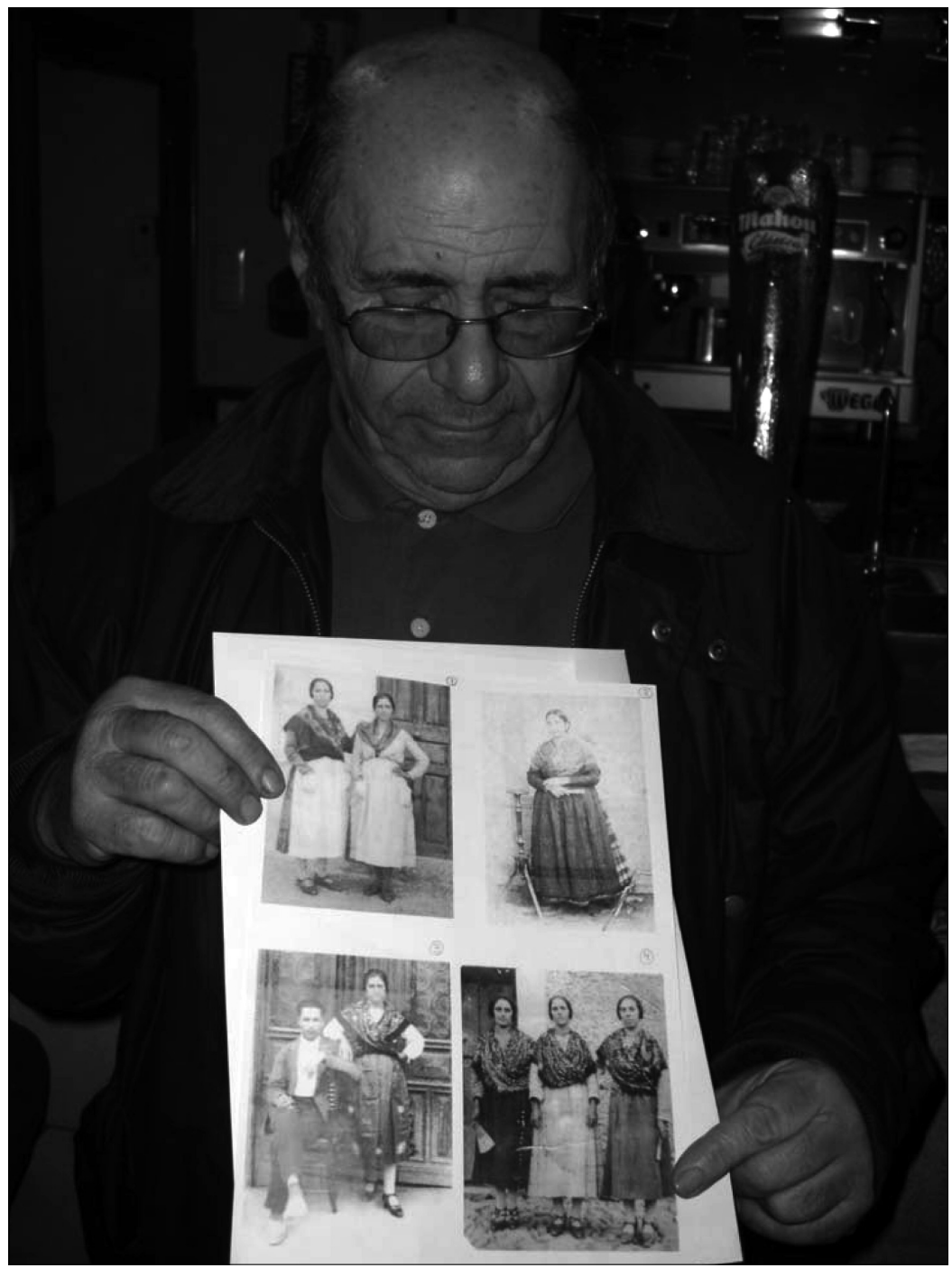

Figura 4: 30 de octubre de 2008. Lucio García Tornero muestra unas fotos familiares en las que aparecen algunas de las personas asesinadas tras el golpe militar de 1936. Como parte del cortocircuito de memoria familiar provocado por esas muertes trágicas, Lucio no podía reconocer con certeza a todas las retratadas en las fotos con trajes regionales, tomadas por fotógrafos ambulantes durante alguna festividad en Villanueva antes de la guerra. "Son fotos que he encontrado en mi casa, no sé bien quiénes son", me dijo. En la foto inferior izquierda, José María Naranjo y su mujer, Ana Tornero Quintana (hermana de la madre de Lucio, embarazada en el momento de su muerte), fusilados respectivamente el 14 y 26 de septiembre de 1936. En la foto inferior derecha, la mujer del centro es la madre de Lucio. A su lado, "sus hermanas o algunas amigas". Fotografía del autor. 
saje desconcertante en su espasmódico oscilar. No era agua, pero tampoco sabía descifrar de qué se trataba.

Al día siguiente, tras ciclos sucesivos de esperanza y desazón, se agotaron las posibilidades en las dos nuevas ubicaciones, sin el más mínimo rastro. En la otra fosa, donde estaban la abuela y dos tías de Lucio, que algunos de los propios familiares empezaron a excavar con azadones, tampoco apareció nada durante el día, y se dio por cerrado el intento de encontrar los restos. La desolación por la falta de resultados concretos en una exhumación en la que se pensaba que se iba sobre seguro - todos los testimonios coincidían aproximadamente en los emplazamientos-, se compensaba en parte por el esfuerzo de, al menos, haberlas buscado hasta el límite de sus posibilidades. Cavando, apartando piedras, ayudando a cribar tierra cuando había hecho falta para tratar de anclar los testimonios en la localización real de la fosa. No todos los familiares presentes compartían la misma opinión sobre la conveniencia de la proyección pública de la excavación, y menos aún sobre la presencia de tantos medios de comunicación. Pero para Lucio, el mero acto de la excavación significaba haber reivindicado con fuerza el recuerdo en el ámbito público, si acaso durante unas horas. No sólo ya en el núcleo familiar, o en el pueblo. Ahora mucha gente en España, y algunos más allá de ella, sabía de la tragedia de estas cinco mujeres. La solicitud de exhumación quedó plasmada de forma notoria en un documento oficial de la Audiencia Nacional. Sus restos, si las localizaciones investigadas eran las correctas, los devoró la tierra. Pero el ciclo no ha terminado: ya se anticipan nuevas prospecciones en la zona (previstas para la primavera de 2009) - basadas en una nueva reconstrucción en espejo de la localización de los hechos desde el camino y la fuente que servían como referencia de los enterramientos-, así como una conmemoración y el desarrollo de una página Web.

Un mes después, el 28 y 29 de noviembre, el equipo técnico regresó al paraje de 'Las Palomas' en el término municipal de Valverde de la Vera, a buscar otras dos fosas con vecinos de Villanueva de la Vera ejecutados también durante el terror caliente del otoño de 1936. Bajo el aguacero, y en un terreno que pronto se convirtió en un gran barrizal, las fosas dieron en este caso al menos una breve pista de que las secuencias de terror y muerte que infiltraban los recuerdos y los testimonios de los familiares y testigos no eran una mera invención paranoica: en el emplazamiento de una de las dos fosas que se buscaban aparecieron tres pares de suelas de calzado que correspondían a los tres fusilados que se estaban buscando: Teodoro Tornero, Lorenzo Cordero y Gregorio Recio. Junto a ellas, un botón rojo y una moneda. En la fosa no quedaba nada más. Escasísimos objetos personales como único rastro de trece fusilados. Pero, aunque no hubiera aparecido 


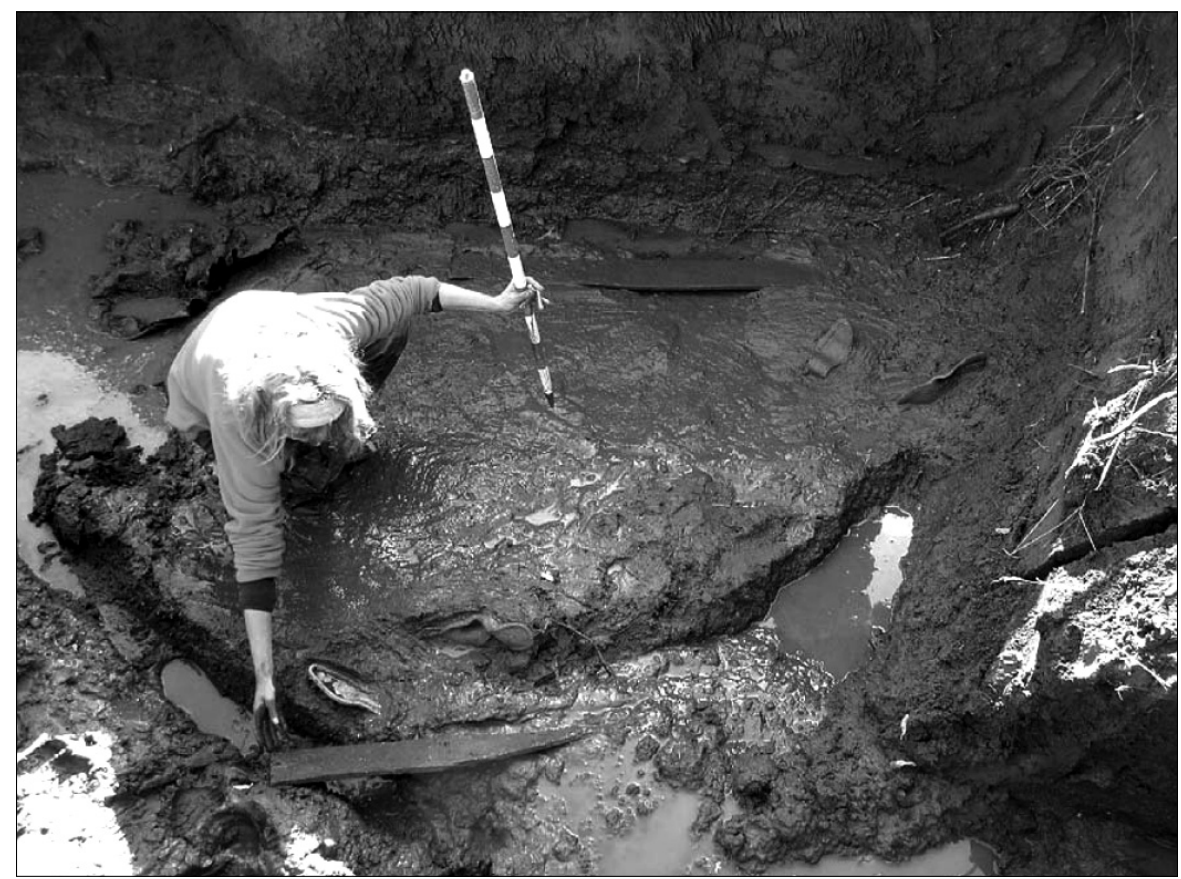

FIGURA 5: 29 de noviembre de 2008. Marisa Hoyos (ARMH) prepara el fotografiado de cuatro de las seis suelas de calzado encontradas en la fosa común donde estaban los restos de Teodoro Tornero, Lorenzo Cordero y Gregorio Recio en Valverde de la Vera. Fotografía anónima descargada de http://lavacamulticolorac.blogspot.com/2008/12/ exhumacin-en-villanueva-de-la-vera-el.html.

prácticamente nada, una parte importante del trabajo estaba hecho. Estaban allí. Ese era el lugar donde les mal enterraron ${ }^{15}$.

\section{'TIRADOS COMO PERROS'}

Parece justo resaltar la importancia que han cobrado las fosas comunes y el campo de fuerza que todavía generan en los debates de la última dé-

15 Sobre la responsabilidad política de la arqueología de la Guerra Civil, y sobre la necesidad de interpretar los lugares de excavación y restos materiales hallados en el contexto de toda la gama de sitios arqueológicos disponibles de la contienda, véase GonzálezRuibal 2007. Para González-Ruibal, la proliferación contemporánea de lugares arqueológicos de la Guerra Civil contrasta con su "invisibilidad social" durante décadas, con excepciones, lo que hasta hace bien poco limitaba su potencial didáctico. Como las fosas comunes, los otros restos de la guerra están en un limbo legal, al no ser reconocidos legalmente como "patrimonio arqueológico" (calificación reservada a los vestigios de más de 100 años), aunque haya habido "interpretaciones generosas" de esta norma (2007: 206-207). 
cada respecto a la memoria de la Guerra Civil, así como en la necesidad de respuesta por parte de diversas instancias del poder político y judicial ante las demandas de algunos sectores de sociedad civil herederos de los vencidos en la guerra, que se van convirtiendo paulatinamente en 'sentido común' democrático. Cada pala excavadora que cae, cada azadón que golpea, cada paleta que aparta la tierra en el entorno de una fosa común o su presunto emplazamiento en algún rincón de España pone en tensión espacios y tiempos disímiles. Lo hace al tiempo que reconfigura, como un calidoscopio en perpetuo movimiento —a veces espasmódico, a veces más sereno-, complejos procesos sociales, políticos, jurídicos y simbólicos. Y que moviliza narrativas locales, discursos políticos, paradigmas historiográficos y científicos, productos mediáticos e intervenciones o recreaciones artísticas de naturaleza muy distinta, incluso opuesta ${ }^{16}$.

En este texto hemos partido de la espectacular, si bien fugaz, intervención de Garzón para llegar a una exhumación —en este caso sin localización de restos- Pero el proceso ha sido el contrario. Garzón, como antes el gobierno de Zapatero, ha tenido que reaccionar ante la presión ejercida en los últimos ocho años por las peticiones de las asociaciones que representan a los descendientes de los vencidos, fundamentada en estrategias 'por elevación' - en las que las propias asociaciones intentan caminar siempre que es posible por delante de las instituciones ${ }^{17}$-, y cimentada en la acumulación paulatina de exhumaciones, cuerpos recuperados, mapas de fosas de diferente escala, listados de represaliados, un emergente ciclo conmemorativo que trenza paulatinamente lugares de represión, asesinatos y masacres, y una presencia desigual pero constante de los debates sobre la 'memoria histórica' en los medios de comunicación, en instituciones académicas —aunque en menor medida - y, como hecho nada desdeñable, en las conversaciones más o menos privadas de muchos ciudadanos en contextos diversos ${ }^{18}$. Es decir, en conjunto, aunque con picos y valles de interés, el debate parece firmemente engranado en el tejido social donde, es también evidente, las posiciones son múltiples, más o menos matizadas y, algunas de ellas, parece que irreconciliables.

Exhumaciones de fosas comunes como las de Villanueva y Valverde forman parte de una compleja y necesariamente controvertida relectura con-

16 Vease Ferrándiz 2006 y 2008.

17 Gracias a Emilio Silva por enfatizar este punto.

18 Este aspecto es también resaltado por Fernández de Mata (2007: 195-208). Sobre el potencial movilizador de la llegada de los debates sobre la memoria histórica a los espacios de experiencia cotidiana, véase el incidente narrado por Silva en la reciente entrevista que le hizo Jo Labanyi (2008: 148-149). 
temporánea de unos hechos trágicos derivados de una política de represión sistemática llevada a cabo por el ejército sublevado, como ya han señalado no pocos historiadores y quedó plasmado en el auto de Garzón. Como resultado de las violencias de retaguardia de ambos bandos contendientes, España se convirtió en un paisaje salpicado de fosas comunes. Como ha señalado recientemente Javier Rodrigo (2008), el reconocimiento de graves abusos en ambos bandos contendientes no es equivalente a su simetría. En su magnífico Hasta la raíz, señala cinco razones por las cuales no es posible, desde el punto de vista historiográfico, sostener ni siquiera la equivalencia de las represiones de retaguardia durante la Guerra Civil. La primera asimetría es cuantitativa, y se refiere a las cifras totales. La violencia golpista fue además mayor porcentualmente respecto al territorio controlado. También se produjo una mayor violencia de las tropas sublevadas en los territorios que cambiaron de manos en los primeros meses de la guerra. Otra asimetría está relacionada con las fechas en las que la fase de terror caliente se transformó en represión fría. Finalmente, a medida que avanzaba la guerra, la retaguardia de las tropas sublevadas se hacía sustancialmente más amplia que la retaguardia republicana. Este mismo autor sostiene, respecto al controvertido problema de las cifras, que en la retaguardia republicana pudieron morir en torno a 55.000 personas, mientras que en la sublevada se pasaría con mucho de las 100.000 (2008: 42-49) ${ }^{19}$.

Tras el fin de la guerra, la represión incluyó, entre sus múltiples modalidades, el abandono despectivo e intencional de las fosas comunes de los derrotados, convertidas en instrumentos del terror permanente, perversos artilugios de una tenebrosa pedagogía de la sangre ${ }^{20}$ que han llegado en buena parte hasta el presente, aunque su eficacia ha ido decreciendo a medida que van muriendo las generaciones que las llevaban inscritas más profundamente en su estructura de sentimientos como paradigma de la represión. Se trataba de un abandono selectivo, que prolongaba la vida útil de los paisajes del miedo y profundizaba el cortocircuito del control familiar, social, político y simbólico de los muertos y los duelos. Sin embargo, aunque el proceso de exhumaciones de las fosas de la derrota contemporáneo causa perplejidad en muchos, estupor en otros tantos, y ha llegado a generar acusaciones de fanatismo, guerracivilismo, anacronismo o incluso necrofilia, España ha sido un país que ha dedicado no pocos esfuerzos a

19 En su resolución de 26 de diciembre de 2008 sobre los niños perdidos del franquismo, divulgada por los medios el 7 de enero de 2009, Garzón avanza que, según sus peritos, el número total de víctimas de la represión puede oscilar entre 136.062 y 152.237 .

${ }^{20}$ Sobre la 'pedagogía de la sangre', véase Rodrigo 2008: 73. 
exhumar la Guerra Civil desde el propio fin de la contienda. Es decir, las exhumaciones contemporáneas ni son una novedad ni están teniendo lugar en el vacío. Lo que sí ha variado sustancialmente es el contexto en el que se están produciendo, y las consecuencias que están teniendo en el replanteamiento de diferentes aspectos de la historia del país, desde el estudio más pormenorizado del alcance de la represión franquista no sólo a corto y medio sino también a largo plazo, hasta el reciente 'tanteo' de esquemas transnacionales de justicia para valorar su posible aplicación el caso español, o el cuestionamiento de los posible límites de la Transición española.

Desde la victoria militar, los muertos del bando vencedor, en frente y retaguardia, fueron en buena parte investigados en la Causa General, localizados, desenterrados, reinhumados, e incorporados a llamativos ciclos conmemorativos y proyectos monumentales aderezados con una abrasadora retórica de heroísmo y martirio ${ }^{21}$. Aunque, a pesar de todos estos procesos, la reactivación conmemorativa de las fosas nacionales en el marco del paradigma de los caídos por Dios y por España no fue completa, y queda por investigar hasta qué punto ciertos sectores del bando vencedor pudieron sentirse violentados o incómodos por esta utilización descarnada del régimen de Franco de los cuerpos y la memoria de sus deudos, el agravio comparativo con las fosas republicanas es evidente. Como vimos, a finales de los años cincuenta hubo un importante movimiento de cadáveres provenientes de fosas comunes relacionado con reinhumaciones masivas en el faraónico Valle de los Caídos, aunque ahora sabemos que incluían también cuerpos extraídos de fosas republicanas que se alojaron allí con el desconocimiento

${ }^{21}$ Véanse el $A B C$, Arriba o Alcázar en los años posteriores al fin de la guerra, donde pueden encontrarse frecuentes reportajes sobre exhumaciones, identificaciones y reentierros de 'mártires', junto a informaciones relativas a funerales públicos, misas solemnes y la erección de monumentos y placas conmemorativas. Sobre su impactante escala ocasional, véase, por ejemplo el $A B C$ del 25 de febrero de 1940, que cubría la exhumación de 1.500 'patriotas' en el cementerio de Moncada en Barcelona. Véanse también las órdenes publicadas en el BOE relativas a las exhumaciones de la posguerra. Por ejemplo, en el BOE del 1 de mayo de 1940, p. 3257, la orden "sobre exhumaciones e inhumaciones de cadáveres de asesinados por los rojos", firmada por Serrano Suñer (gracias a Carlos Agüero por facilitarme esta información). Paradójicamente, como señalan autores como Javier Rodrigo, la Causa General, concebida como versión oficial del llamado "terror rojo" ha tenido como consecuencia imprevista a largo plazo la inhibición de la investigación contemporánea sobre las fosas franquistas y ciertos hechos de violencia en la retaguardia republicana, cuyo debate se sigue moviendo en el ámbito de los "mitos, anatemas y justificaciones" más que en el de las investigaciones rigurosas (2008: 83). Sobre este particular, y sobre la importancia de prestar también atención a las "fosas de la República", véase el instant book de Ranzato (2006: 97-112). Sobre las políticas de la memoria durante el franquismo, véase Aguilar (2008: 95-231). 

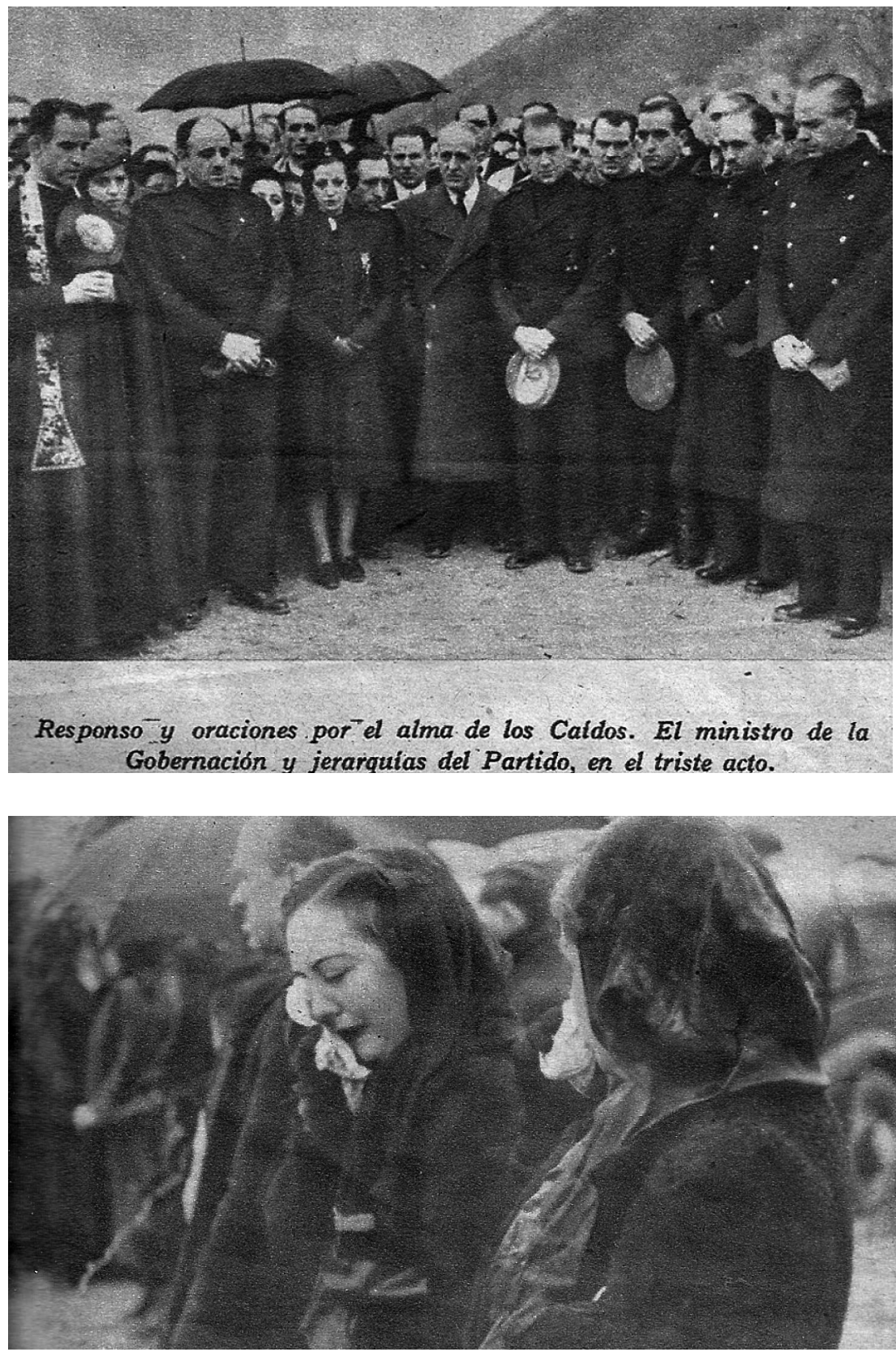

FiguRa 6: Conmemoración oficial y duelo familiar en Paracuellos del Jarama a finales de 1939. Fotos publicadas en el Semanario Gráfico Nacional Sindicalista, Año 3, número 143, 25 de noviembre de 1939. El pie de foto original de la segunda imagen dice: "Llanto incontenible el de la hija, en la evocación de aquel trágico cuadro de 1936". 
de sus familiares, bajo los auspicios de una placa que reza 'Caídos por Dios y por España 1936-1939 RIP' y coronados, como todos los cuerpos allí enterrados, por las tumbas, ahora probablemente inquietas, de José Antonio Primo de Rivera y Francisco Franco. Historiadores de prestigio como Julián Casanova han expresado recientemente su sorpresa ante el secretismo que todavía envuelve el número y origen de los cuerpos trasladados al Valle, especialmente entre 1958 y 1959. Aunque en su pionero libro Daniel Sueiro (2006 [1976]) calcula que podía haber allí en torno a 20.000 cuerpos a principios de 1959, y Queralt Solé (2008: 57-90) estima que la cifra oscilaría entre 20.000 y 30.000, el número total puede ser muy superior ${ }^{22}$. En todo caso, la escala del traslado de cadáveres de la Guerra Civil hacia a este monumento es sobrecogedora.

Posteriormente, durante los primeros años de la Transición, grupos de familiares abrieron algunas de las fosas republicanas con escaso o nulo apoyo institucional o técnico, aunque estas iniciativas disminuyeron tras el golpe de estado de 1981 (Ferrándiz 2008). Es necesaria todavía mucha investigación sobre estas exhumaciones ya que, a medida que se extienden las tareas de recuperación de cuerpos en la España contemporánea, aparecen con frecuencia nuevos datos y su número y escala parece ser mayor de lo anticipado $^{23}$. En una iniciativa relacionada algo más tangencialmente con las víctimas directas de la Guerra Civil, el Ministerio de Defensa suscribió en septiembre de 1995 un convenio con Volksbund, una fundación alemana que se encarga de la búsqueda de los desaparecidos en la Segunda Guerra Mundial, con el fin de exhumar, y en algunos casos repatriar, los cadáveres de soldados de la División Azul muertos en la batalla de Leningrado que

${ }^{22}$ Véase el artículo de opinión de Julián Casanova en El País, 20-11-07, p. 33, donde apunta que el número total de cadáveres enterrados bajo la cripta podría llegar a los setenta mil. En el documental Franco: Operación caídos emitido el 28 de enero de 2009, ya mencionado en la nota 2, el propio Abad del Valle de los Caídos, el padre Anselmo, declaraba a la cámara que "oficialmente, según los libros, serían 33.897. Pudieron ser bastantes más (...) Por otra parte, con la finalidad de no alarmar excesivamente sobre la cantidad de muertos que venían al Valle, etcétera, el cálculo que se hizo fue casi sistemáticamente a la baja. El número real era bastante superior al número reflejado oficialmente". Ante la pregunta, "¿se atrevería a dar una cifra oficiosa de las personas que pudieran estar aquí enterradas?", respondió: "Menciono la que... entre los encargados de esta operación... estaba muy cerca de las 60.000 personas". Sobre la complejidad y posibles ambigüedades contenidas en el monumento, véase Aguilar 2008, pp. 146-158. Para esta autora, "el indicio de reconciliación sólo afecta, tardíamente por lo demás, a algunos muertos del bando republicano pero en ningún caso a los supervivientes del mismo" (ibid., p 156).

${ }^{23}$ Algunas de estas exhumaciones transcendieron a la opinión pública nacional, especialmente en las páginas de la revista Interviú. 
se encontraban enterrados en varios cementerios rusos ${ }^{24}$. Pero fue la iniciativa de Emilio Silva de promover la exhumación de una fosa común republicana en Priaranza del Bierzo (León) en octubre de 2000, que contenía trece cuerpos, entre ellos el de su abuelo, la que puso en marcha un nuevo capítulo en la compleja política española de la memoria respecto de la Guerra Civil. Esta exhumación se hizo ya con la presencia de especialistas (arqueólogos y forenses) y dio lugar a un informe técnico (Silva 2005: 5162). Desde entonces, se han abierto en torno a doscientas fosas recuperando más de cuatro mil cuerpos ${ }^{25}$. El 'trabajo de la memoria' se ha diversificado enormemente, con un recorrido social, simbólico y político muy extenso y profundo que ni los más visionarios podían anticipar en un principio (Jelin 2003). En este proceso, las fosas comunes de la derrota han pasado de ser vertederos políticos, emocionales y simbólicos, artefactos averiados de la maquinaria de terror franquista, a convertirse en poderosas herramientas de movilización del debate público. Está claro que el impacto mediático de su apertura en la sociedad de la información y el conocimiento ha sido muy importante. Pero las dimensiones que están cobrando en la sociedad espa-

${ }^{24}$ Se calcula que sirvieron en torno a 47.000 soldados en la División Azul, y el número total de muertos ronda los 5.000. En una respuesta escrita a una pregunta de Amparo Valcarce (Grupo Socialista) sobre los trabajos realizados por la fundación Volksbund a petición del Ministerio de Defensa, publicada en el Boletín Oficial de las Cortes generales de 6 de marzo de 2003, el Gobierno informó que el total de exhumaciones hechas desde 1997 hasta 2001 era de 1.162 cadáveres de la División Azul, desenterrados en quince cementerios distintos. La intención era reinhumar un buen número de ellos en un sector ad hoc remodelado específicamente para recibir estos cuerpos del cementerio militar alemán de Pankovka (Novgorod, Rusia), que había sido el cementerio de la $1^{\underline{a}}$ División de la Luftwaffe. En la respuesta, se afirmaba que ya había allí enterrados 829 cadáveres, y que se contemplaba presupuesto para un monolito, placas con los nombres de los enterrados, los caminos de acceso y abetos para rodear el monumento. Hasta ese momento, la cantidad abonada para acopio documental, estudio topográfico y exhumación era de $90.000 €$, estimándose los gastos de acondicionamiento del cementerio en o más de $40.000 €$. Véase http://www.congreso.es/public_oficiales/L7/CONG/ BOCG/D/D_500.PDF\#page=311.

${ }^{25}$ La casuística de las fosas es muy variada, y varía desde fosas independientes a otras que contienen cientos, incluso miles de cadáveres. Para apreciar la progresión, aunque no se trata de datos oficiales, basten dos ejemplos. En el dossier sobre fosas comunes incluido en el número 299 de la revista de historia y cultura L'Avenç (2005) se contabilizaban 60 fosas exhumadas desde el año 2000, con un total de 469 cuerpos recuperados. En septiembre de 2008, en uno de los suplementos dominicales de El País, basándose en datos propios y otros aportados por la ARMH, AGE-MHA, la Generalitat de Cataluña y la Junta de Andalucía, el periódico contabilizaba más de 4.000 cuerpos exhumados en 171 fosas desde el año 2000. Esas cifras, ya de por sí tentativas, quedaron obsoletas enseguida. Véase El País, Domingo, 14-09-08, p. 4. 
ñola los debates sobre las políticas de la memoria no pueden ser sólo fruto de la proyección mediática y 'consumo rápido' de restos humanos desente-

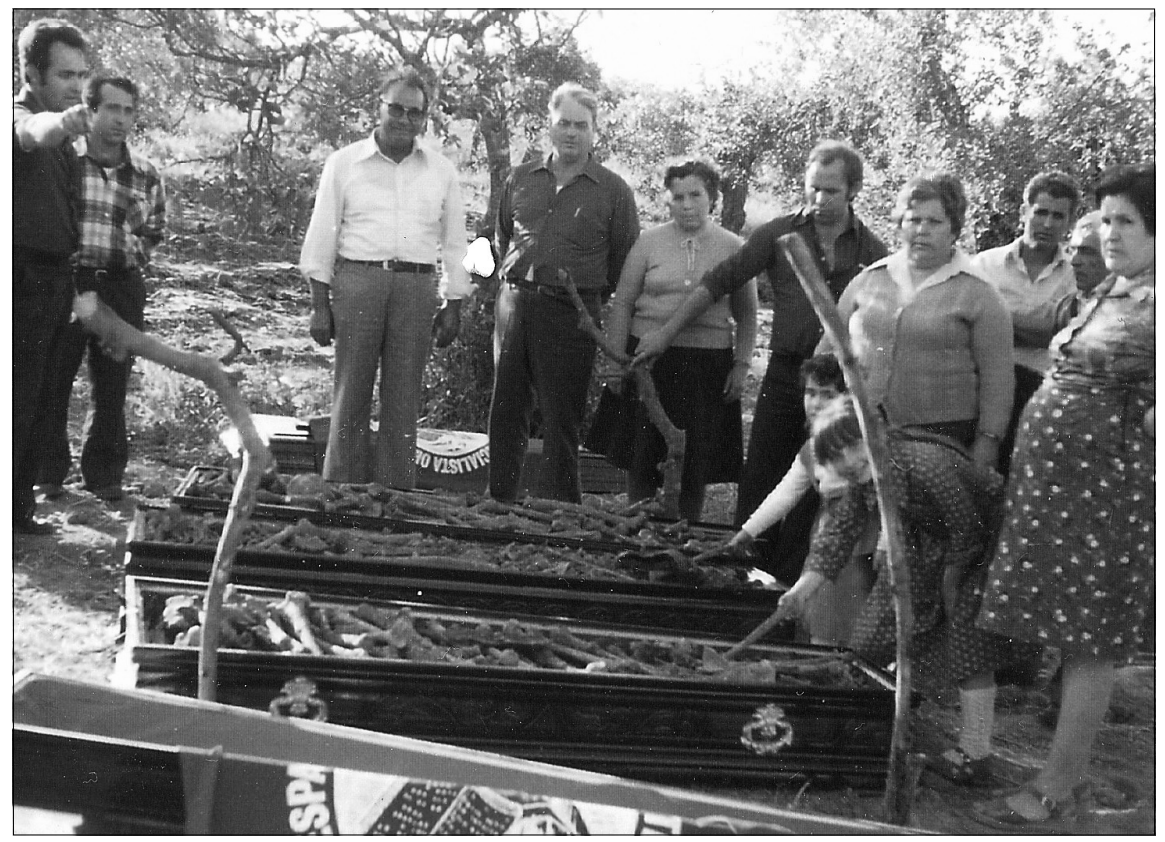

Figura 7: Posado colectivo tras una exhumación llevada a cabo por familiares de represaliados del franquismo en Casas de Don Pedro (Badajoz) en 1978. La ausencia de apoyo técnico en este ciclo de exhumaciones se expresa en la indiferenciación de los restos acumulados en los ataúdes. Foto cortesía de Emilio Silva.

rrados después de setenta años con impactantes signos de violencia, sino que responden a una corriente más de fondo que, latente, apenas precisaba de un resquicio para emerger.

Que, como sostiene Robben (2000: 93-97), la presencia continuada de fosas comunes y colectivos de personas desaparecidas tiene el potencial para inyectar grandes cantidades de desorden, ansiedad y división en una sociedad determinada a corto, medio y largo plazo, puede fácilmente comprobarse en el caso español. Paisajes de terror paralizantes durante los momentos más duros de la represión, distribuidores de miedo durante décadas, controvertidos en el presente. Los campos de desconocimiento, ambigüedad y desconfianza que generan las fosas comunes de la Guerra Civil en tanto que espacios de muerte desplegados simultáneamente en "hermenéuticas de sos- 
pecha y revelación" (Taussig 1987: 10), esculpidos disparo a disparo y palada a palada para la parálisis política, social, económica y emocional de los adversarios durante la contienda y, posteriormente, de los derrotados, han evolucionado con el tiempo llegando hasta el presente, quizá sorprendentemente, como un daño sobrevenido, demorada su gestión durante décadas. Que los desaparecidos y las exhumaciones hayan llegado hasta Garzón, y Garzón hasta las figuras jurídicas relativas a los crímenes contra la bumanidad, no es sino un ejemplo de su eficacia todavía operativa, si bien muy diferente de la originaria, y de la necesidad de una solución permanente. También indica la imposibilidad de barrer bajo la alfombra los trapos sucios de la contienda esperando su desactivación espontánea. Por un lado su carácter de secreto público, el hecho de estar aprisionadas bajo el desprecio de los vencedores y el silencio impuesto a las víctimas de esa violencia, impidieron el surgimiento de relatos socialmente legitimados sobre el terror que contienen, así como de espacios consolidados de duelo. Por otra parte, la distribución de fosas por todo el territorio nacional tiene una intencionalidad ejemplarizante expresada en una densa topografía del terror que ha permitido a la maquinaria de la muerte y de la producción masiva de miedo operar a pleno rendimiento y a gran escala.

La creciente oleada de indignación de los familiares de estos fusilamientos de retaguardia, que se despliega por asociaciones, exhumaciones, reinhumaciones y actos conmemorativos de diversa índole, que se ha expandido por la sociedad civil (no sin respuesta) y ha llegado a presionar a ciertos gobiernos autonómicos e incluso al de la nación para que proporcionen financiación y apoyo logístico o desarrollen legislación, como hemos visto, tiene entre sus múltiples elementos constitutivos la idea de la fosa común como forma de entierro infrahumano que necesita corregirse para poder plantear esquemas de reconciliación efectivos. Los discursos contemporáneos de las asociaciones para la recuperación de la memoria histórica están permanentemente en transformación a través del reciclaje de campos semánticos, conceptos y expresiones de diversa proveniencia, desde expresiones populares hasta términos jurídicos técnicamente complejos ${ }^{26}$. Su evolución en la última década es del mayor interés para cualquier estudioso de las políticas de la memoria en la España contemporánea. En este contexto, hay un aspecto esencial de la justificación de la idoneidad de las exhumaciones y del manejo adecuado - especialmente político y simbólico- de los restos con posterioridad en una 'cadena de custodia' que, si no está claramente establecida y consensuada entre todos los actores sociales implicados, puede

\footnotetext{
${ }^{26}$ Sobre el surgimiento de la memoria histórica en la España contemporánea desde una perspectiva antropológica, véanse Ferrándiz 2005 y Fernández de Mata 2007.
} 
provocar malentendidos y disputas. En efecto, una de las razones del impulso desenterrador de los últimos años es la noción tan extendida, entre muchos familiares y activistas de la memoria, de la fosa común como una forma de entierro infrahumano —originado intencionalmente como tal por los pistoleros franquistas-, cristalizado en la expresión tirados como perros, o en otras ocasiones, enterrados como perros, usada con mucha frecuencia para describir la percepción colectiva de las fosas comunes de la derrota y que, ya vimos, también utilizaba la madre de Lucio para referirse a sus seis familiares fusilados en Villanueva, entre ellas su madre, dos hermanas y un hermano ${ }^{27}$. Esta noción, que significa el mal entierro, el entierro insuficiente, el entierro ofensivo, el entierro de castigo, el entierro animal tras una muerte, fruto de una represión salvaje, el entierro destinado a excluir a los fusilados de la propia comunidad de los muertos, sin sus ritos, sin sus duelos, amontonados, indiferenciados, desarreglados, "tirados", enredados todavía en la violencia que acabó con ellos, congelados hasta el día de hoy en los estertores del fusilamiento, es básica en la movilización de muchas de las personas que buscan los restos de sus familiares para darles, también en esta lógica, un entierro digno que le diferencia del de los perros y alimañas. Cuando le pregunté a Lucio a qué se refería su madre cuando usaba esta expresión, me contestó, "ella sentía que no estaban en el cementerio, como las 'personas', que no le habían dejado llorarlas, que estaban allí sin honras fúnebres". En este sentido, el proceso de exhumación y reinhumación de los restos supondría un proceso simultáneo de rehumanización, revirtiendo así un esquema sistemático de represión, disciplinamiento y disposición intencionalmente ofensiva de los cadáveres en fosas sin nombre que 'teorizó' y 'trató' a los destinatarios de la violencia sublevada y luego franquista como 'infrahumanos' (Rodrigo 2008: 62) ${ }^{28}$.

${ }^{27}$ Se trata sin duda de una expresión muy popular, que se escucha con mucha frecuencia en el entorno de las fosas. Esta expresión no falta tampoco en la controversia que mantiene Ian Gibson con los familiares de García Lorca. Según ha declarado el hispanista, partidario militante de la exhumación del poeta, "Lorca yace tirado en una cuneta como un perro". Véase, por ejemplo, http://www.lukor.com/not-soc/cuestiones/ portada/08091213.htm.

${ }^{28}$ Aunque el análisis detallado de la construcción de los rojos como miembros de una anti España que debía ser erradicada queda fuera de los objetivos de este artículo, es interesante mencionar en este punto que en el auto de Garzón de 16 de octubre de 2008, en la página 12 - y citando como fuente a Francisco Espinosa (2006)—, se recogen unas palabras de Queipo de Llano en Radio Sevilla en 1936 en las que afirmaba, justificando la impunidad y resaltando la condición subhumana de los enemigos: "Yo os autorizo a matar, como a un perro, a cualquiera que se atreva a ejercer coacción ante vosotros: que si lo hicierais así, quedareis exentos de toda responsabilidad". Véase también Rodrigo 2008: 62-64. 


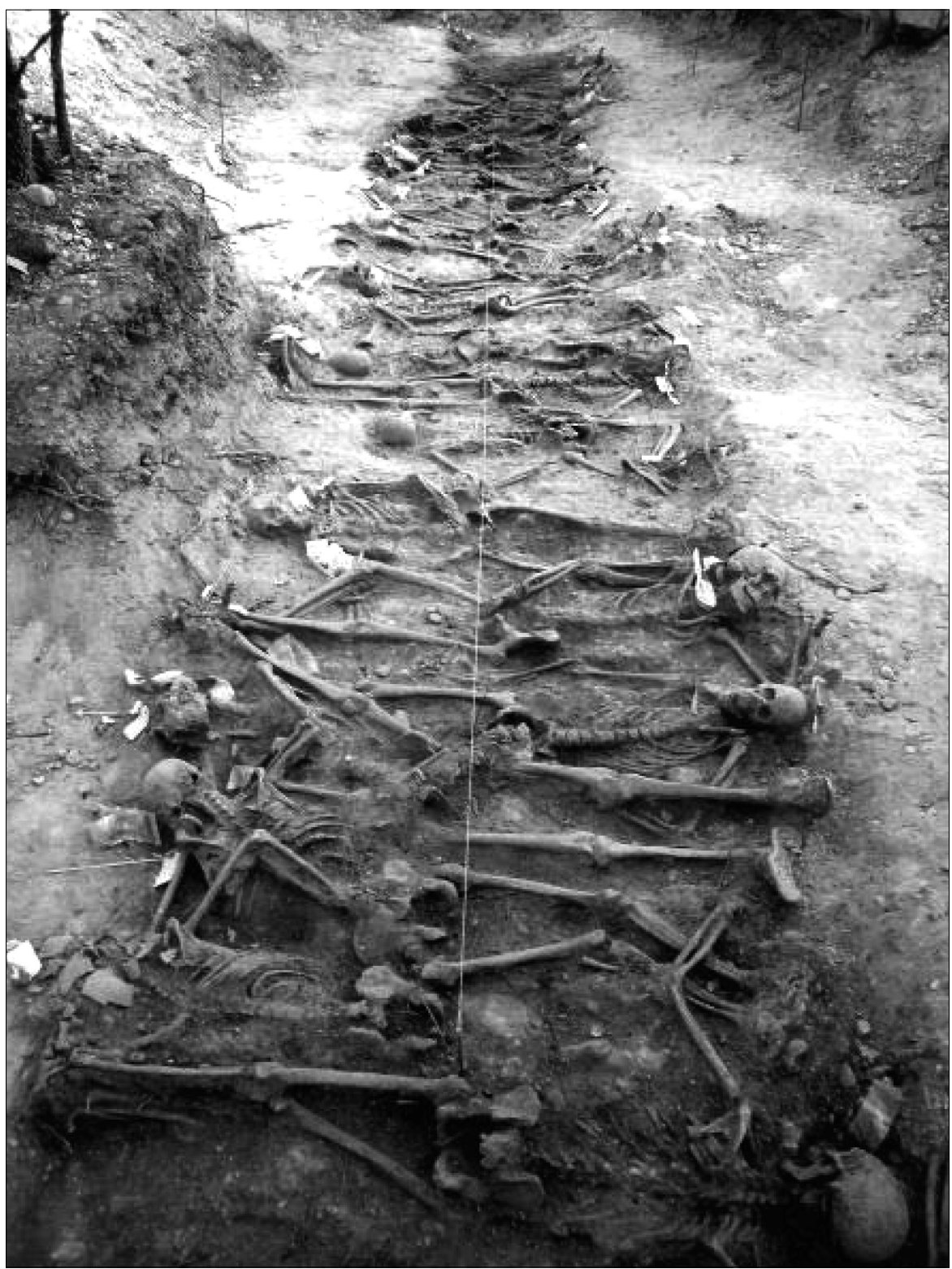

Figura 8: Restos de las 47 personas exhumadas en Villamayor de los Montes (Burgos) en julio de 2004. La foto - que en 2005 fue la base de un llamativo póster que anunciaba una conferencia internacional en la Universidad de Notre Dame (Indiana), y apareció en la portada de uno de los hasta ahora tres informes de Amnistía Internacional sobre las exhumaciones en España, titulado "España: Poner fin al silencio y a la injusticia"- se ha convertido en una de las imágenes emblemáticas de las fosas del franquismo. Foto, cortesía de Francisco Etxeberria. 
La dignificación de los cuerpos tirados o enterrados como perros en cunetas, simas, pozos o fosas forma parte de una cultura política en expansión y transformación, y tiene muchos sentidos dependiendo de los colectivos de la memoria de los que se trate. En un texto anterior (2005), planteaba las controversias que se habían producido en los primeros años entre diversas asociaciones a la hora de revertir el rasgo deshumanizador de la violencia y la represión franquista, tal y como se expresaba en el enterramiento en fosas. En todos los casos, se estaba poniendo en marcha un proceso de neoritualización sin precedentes, ante la ausencia de pautas consolidadas para conmemorar, o exhumar y reinhumar cuerpos exhumados más allá de las ceremonias religiosas o de los rituales de Estado franquistas. En el primer caso discutibles para muchos, aunque satisfactorios para otros y, en el segundo, lógicamente, inviables. Para algunas asociaciones, como la que custodia la fosa común de Oviedo, la dignificación más adecuada precisaba de la preservación de la fosa sin excavar, para mantener latente el potencial didáctico de la barbarie en el propio desorden e inhumanidad del entierro. Desenterrar, en esta lógica, sería borrar la página más explícita de la crueldad de la represión. Otras pensaron desde el principio que dignificar implicaba necesariamente exhumar cuando y donde fuera posible, y reubicar los restos, desencadenando un complejo y delicado recorrido post mórtem que prolonga lo que Verdery ha caracterizado como la vida politica de los cadáveres (1999), recorrido que comenzó en los propios fusilamientos y en los enterramientos en fosas comunes (de ambos bandos), entendidos como instrumentos del terror político. Verdery insiste en la importancia de descifrar el "tipo de tiempo que se congela" (ibid.: 12) en la disposición política de los cuerpos, como lo es desentrañar el contexto histórico desde el que se rescuperan y reinterpretan dichos restos. Pero en este punto, más allá de las convergencias de base entre las asociaciones pro-exhumadoras, se han consolidado sensibilidades discrepantes sobre cómo pilotar esta nueva vida política de los cuerpos fusilados de los derrotados en la Guerra Civil que, como ya hemos visto, es el episodio más reciente de una secuencia de exhumaciones de fosas nacionales y republicanas que empezó con el propio fin de la guerra ${ }^{29}$. Dentro de estos grupos, para algunos son los familiares los que tienen potestad para generar y reciclar los circuitos religiosos,

29 Algunos intelectuales, activistas y comunicólogos han sugerido la apertura de una nueva fase vinculada a la repatriación de los cuerpos de algunos españoles ilustres que murieron en el exilio, aunque de momento se trata de gestos fundamentalmente retóricos. Véase, por ejemplo, el texto de opinión de Benjamín Prado “¿Por qué no traer a España a Machado y Azaña?" publicado en El País de 16 de noviembre de 2008, donde el autor defiende la importancia simbólica y política de hacerles un entierro honroso en su propio país. 
políticos, simbólicos y emocionales que consideren oportunos para exhumar y reinhumar los cadáveres, incluyendo el muy solicitado pero a veces controvertido tránsito de la fosa a la cristiana sepultura. Para otros grupos, la politización de todo el proceso según pautas rituales de la izquierda que, cada vez más, incluyen referentes republicanos, es un imperativo de dignificación, al tratarse originariamente de crímenes políticos. La intervención de la Iglesia sería, para esta última sensibilidad, completamente contraproducente, dada su implicación en no pocos de los paseos, su cobertura ideológica de la guerra y el franquismo, y su negativa actual a apoyar el proceso de exhumaciones - consideradas divisivas por sus portavoces-, mientras promueve la beatificación de mártires víctimas de la represión republicana $^{30}$.

Aunque también pueden desencadenarse discrepancias respecto a su cariz y contenido, y a sus contextos de enunciación y escucha, un elemento de dignificación más consensuado es la narración, por parte de los a veces llamados donantes de memoria, de las biografías de los fusilados y de los actos de violencia que sufrieron. La narración y registro de testimonios de familiares y testigos, como en el caso de Las Albarizas de Villanueva de la Vera, se han convertido en un eje central del repertorio de acciones de 'recuperación de la memoria'. Para las asociaciones, estas narrativas tienen un doble efecto terapéutico. En el nivel personal, en no pocos casos, quiebran décadas de miedo, vergüenza y humillación. En el nivel social, al transferirse a la esfera pública y cobrar visibilidad y legitimidad, tendrían como consecuencia el reconocimiento del papel histórico de las victimas de la represión franquista, en lo que sería un acto de justicia histórica y de reconocimiento colectivo de su sufrimiento ${ }^{31}$. Aunque estas memorias orales han sido cuestionadas por algunos historiadores ${ }^{32}$, su profusión y su creciente demanda implican que no todos los espacios de narración —en este caso, de la derrota- están agotados en la sociedad española, a pesar de la sensación de saturación producida por la acumulación del importante trabajo historiográfico, la profusión de discursos políticos, mediáticos y ahora jurídicos, y la industrial cultural que está emergiendo en el país en los últimos años

\footnotetext{
${ }^{30}$ Como la reciente y muy controvertida beatificación de 498 "mártires" de la Guerra Civil el 28 de octubre de 2007 en la plaza de San Pedro de Roma. Acto destinado, en palabras del papa Benedicto XVI, al fomento de la "misericordia, reconciliación y convivencia pacífica".

31 Luis Díaz me señala la importancia que puede tener en este contexto el 'poder contarse' para reconstruir una 'identidad humana'.

${ }^{32}$ Véase, por ejemplo, la controversia entre Espinosa (2007), Juliá (2007) y Ruiz Torres (2007a y 2007b) en la revista digital Hispania Nova.
} 
(Ferrándiz 2008). Como ha señalado Paloma Aguilar recientemente, la presunta madurez democrática del país se está poniendo a prueba en su capacidad de absorber o no cualquier debate — por más complicado que sea-, sobre las políticas de la memoria de la Guerra Civil, asumiendo su pluralidad y acomodando las peticiones y aspiraciones que tengan un apoyo social significativo (2007: 68). En este contexto, estas narrativas de la derrota contemporáneas, contadas en el entorno de exhumaciones y otros lugares de la memoria y la conmemoración, parecen tener potencial para escapar de su presumible destino de deshechos discursivos de la Transición y reclamar un papel más central en las políticas de la memoria de la España actual $^{33}$. No como discursos objetivos y verificables sobre el pasado, sino como tramas de memoria desiguales, fragmentarias y múltiples que han de ser descifradas en su complejidad en el contexto del presente desde el que se recuerda: una sociedad de la información saturada, con ciclos de atención cortos y espasmódicos y con amplias oportunidades para la espectacularización del sufrimiento. No como generadoras de formas de victimización acríticas, homogéneas o caricaturescas, sino como fundamentos imprescindibles de un sistema democrático más profundo que pueda contenerlas sin ocultarlas, ignorarlas o denigrarlas, en el contexto de tramas múltiples e incluso contradictorias de la guerra, desde las más intuitivas a las más científicas (Ferrándiz 2008).

Pero el concepto de dignificación, como el resto de facetas de un proceso que es sumamente dinámico y adquiere en ocasiones un ritmo vertiginoso, también se transforma, enriquece y diversifica. En la actualidad, para muchos de estos colectivos, dignificar sigue incluyendo en su repertorio el nombrar, narrar, identificar, excavar, reenterrar, conmemorar y erigir monolitos, cada colectivo o núcleo de familiares según su estilo, influidos mutuamente a pesar de las polémicas, alimentados también por nuevos elementos conmemorativos provenientes de otras latitudes. Por ejemplo, los primeros retratos y fotografías de fusilados que los familiares desempolvaban, llevaban y compartían con los presentes en las exhumaciones (como los mostrados por Lucio García Tornero en la figura 4) han ido evolucionando hacia usos más políticos de estas imágenes — a medida que se consolida y populariza la categoría de desaparecidos para hablar de los fusilados-, como

33 En su estudio sobre las exhumaciones en Guatemala, Sanford resalta la importancia de estudiar los procesos de paz y reconciliación desde abajo hacia arriba (2003: 122). Asimismo, anima a los investigadores a buscar los rastros de la violencia en la propia estructura narrativa de los testimonios. Así, "el legado del trauma está embebido en el lenguaje, como lo está en el resto de las estructuras de la cultura” (ibid:: 18). Eso es así también en el caso español, en lo que podríamos caracterizar como una inscripción a largo plazo recreada desde el presente. 
reciclaje local de esas imágenes paseadas por sus familiares y amigos que, como dice Dorfman, se han convertido en una "extendidísima, casi epidémica imagen de tragedia y resistencia que ya forma parte de nuestra imaginación planetaria tanto como lo puedan hacer las ubicuas marcas y logos comerciales". Para Dorfman, el uso público de estas imágenes transgresoras y de enorme poder iconográfico en manifestaciones o concentraciones son la respuesta más apropiada a las desapariciones, al revertir las políticas de invisibilización de las víctimas al tiempo que se relacionan con los nuevos medios de comunicación con "extrema eficacia y extraordinaria poesía" (2006: $256)^{34}$. En este creciente entrelazamiento de los actos de dignificación de los vencidos de la Guerra Civil española con modalidades de homenaje, recuerdo y reparación que forman ya parte de un repertorio transnacional, para un número creciente de asociaciones y familiares este proceso tiene ya, como insoslayable objetivo básico, el reconocimiento público (e idealmente jurídico, a pesar del descarrilamiento actual de la causa emprendida por Garzón) de que esas muertes formaron parte de un plan sistemático de exterminio y, por lo tanto, de acuerdo con la legislación internacional de derechos humanos, de que son crímenes contra la humanidad.

\section{BIBLIOGRAFÍA CITADA}

Aguilar, P. 1996. Memoria y olvido de la Guerra Civil española. Madrid: Alianza.

Aguilar, P. 2007. "Los debates sobre la memoria histórica". Claves de Razón Práctica 172: 64-8.

Aguilar, P. 2008. Políticas de la memoria y memorias de la politica. Madrid: Alianza.

Dorfman, A. 2006. "The Missing and Photography: The Uses and Misuses of Globalization", en J. Santino (ed.), Spontaneous Shrines and the Public Memorialization of Death: 255-260. Nueva York: Palgrave Macmillan.

Espinosa, F. 2006. La Justicia de Queipo. Madrid: Editorial Crítica.

Espinosa, F. 2007. "De saturaciones y olvidos: Reflexiones en torno a un pasado que no puede pasar". Revista de Historia Contemporánea Hispania Nova 7. http://hispanianova. rediris.es/7/dossier.htm

${ }^{34}$ La Federación Estatal de Foros por la Memoria, en carta firmada por José María Pedreño, convocó para el 1 de febrero de 2008 concentraciones delante de juzgados de toda España, proponiendo a los asistentes llevar pósters de 'nuestros familiares y otras víctimas del franquismo' bajo el lema “Justicia, Verdad y Reparación”, para denunciar la 'absoluta indefensión de las víctimas del franquismo' tras la decisión de la Sala de lo Penal de la Audiencia Nacional. Puede consultarse la convocatoria en http://www.foro porlamemoria.info/media/2004/379_1_Carta_movilizacion.pdf, y algunas imágenes de las concentraciones en: http://www.foroporlamemoria.info/noticia.php?id_noticia=5886. Sobre la controversia en torno al uso del termino 'desaparecidos' véase la nota 3. Sobre la popularización de estas iconografías transnacionales en el marco de la digitalización de la memoria traumática en el caso de la Guerra Civil, véase Ferrándiz y Baer (2008). 
Fernández de Mata, I. 2007. "El surgimiento de la memoria histórica: Sentidos, malentendidos y disputas", en L. Díaz Viana y P. Tomé (coords.), La tradición como reclamo: 195-208. Salamanca: Junta de Castilla y León.

Ferrándiz, F. 2005. "La memoria de los vencidos de la guerra civil: El impacto de las exhumaciones de fosas en la España contemporánea", en J. M. Valcuende y S. Narotzky (eds.), Las políticas de la memoria en los sistemas democráticos: Poder, política y mercado: 109-32. Sevilla: ASANA.

Ferrándiz, F. 2006. "The Return of Civil War Ghosts: The Ethnography of Exhumations in Contemporary Spain". Anthropology Today 22 (3): 7-12.

Ferrándiz, F. 2008. "Cries and Whispers: Exhuming and Narrating Defeat in Spain Today". Journal of Spanish Cultural Studies 9 (2): 177-192.

Ferrándiz, F. y A. Baer. 2008. "Digital Memory: The Visual Recording of Mass Grave Exhumations in Contemporary Spain". Forum Qualitative Sozialforschung/Forum: Qualitative Social Research [Revista on-line], 9 (3): Art. 35.

Gatti, G. 2008. El detenido-desaparecido: Narrativas posibles para una catástrofe de la identidad. Montevideo: Trilce.

González-Ruibal, A. 2007. "Making Things Public: Archaeologies of the Spanish Civil War". Public Archaeology 6 (4): 203-226.

Jelin, E. 2003. State Repression and the Labors of Memory. Mineápolis: University of Minnesota Press.

Juliá, S. 2007. "De nuestras memorias y nuestras miserias". Revista de Historia Contemporánea Hispania Nova 7. http://hispanianova.rediris.es/7/dossier.htm

Labany, J. 2008. "Entrevista a Emilio Silva". Journal of Spanish Cultural Studies 9 (2): 143155.

Marcus, G. E. 1995. "Ethnography in/of the World System: The Emergence of Multi-Sited Ethnography". Annual Review of Anthropology 24: 95-117.

Pile, S. 1997. "Introduction: Opposition, Political Identities and Spaces of Resistance", en S. Pile y M. Keith (eds.), Geographies of Resistance: 2-32. Londres: Routledge.

Ranzato, G. 2006. El pasado de bronce: La herencia de la guerra civil en la España democrática. Barcelona: Destino.

Robben, A. 2000. "State Terror in the Netherworld: Disappearance and Reburial in Argentina", en J.A. Sluka (ed.), Death Squad: The Anthropology of State Terror. 91-113. Filadelfia: University of Pennsylvania Press.

Rodrigo, J. 2008. Hasta la raiz: Violencia durante la Guerra Civil y la dictadura franquista. Madrid: Alianza.

Ruiz Torres, P. 2007a. "Los discursos de la memoria histórica en España". Revista de Historia Contemporánea Hispania Nova 7. http://hispanianova.rediris.es/7/dossier.htm

Ruiz Torres, P. 2007b. "De perplejidades y confusiones a propósito de nuestra memoria". Revista de Historia Contemporánea Hispania Nova 7. http://hispanianova.rediris. es/7/dossier.htm

Sanford, V. 2003. Buried Secrets: Truth and Human Rights in Guatemala. Nueva York: Palgrave MacMillan.

Silva, E. 2005. Las fosas de Franco. Madrid: Temas de hoy.

Solé i Barjau, Q. 2008. Els morts clandestins: Les fosses comunes de la Guerra Civil a Catalunya (1936-1939). Barcelona: Editorial Afers.

Sueiro, D. 2006 [1976]. El Valle de los Caídos: Los secretos de la cripta franquista. Madrid: La Esfera de los Libros.

Taussig, M. 1987. Shamanism, Colonialism and the Wild Man: A Study in Terror and Healing. Chicago: The University of Chicago Press. 
Verdery, K. 1999. The Political Lives of Dead Bodies. Nueva York: Columbia University Press.

Vinyes, R. 2002. Irredentas: Las presas políticas y sus bijos en las cárceles franquistas. Madrid: Temas de Hoy.

Vinyes, R., M. Armengou y R. Belis. 2002. Los niños perdidos del franquismo. Barcelona: Plaza y Janés.

Fecha de recepción: 5 de enero de 2009

Fecha de aceptación: 23 de febrero de 2009 